\title{
Understanding Kaye Scholer: The Autonomous Citizen, the Managed Subject and The Role of the Lawyer
}

\author{
Nancy Amoury Combs $\dagger$
}

The Office of Thrift Supervision's (OTS) unprecedented enforcement action against Kaye, Scholer, Fierman, Hays and Handler (Kaye Scholer) prompted howls of protest from the legal community. OTS, it was claimed, was using its excessive power to redefine the role of the lawyer. This Comment confirms that OTS sought to impose duties on Kaye Scholer that conflict with professional ethics rules. The Comment then goes on to suggest that the conflict over professional responsibility in the Kaye Scholer case reflects, more fundamentally, a conflict over the role of the citizen, and the citizen's relationship with the state. Our adversarial system of dispute resolution is founded on our democratic assumption of citizen autonomy. Citizens are presumed to have independent interests and goals that the state must take into account when it regulates their activities. By contrast, OTS views the thrifts it regulates not as autonomous citizens but as instrumental means of achieving OTS goals. This Comment contends that it is this divergence in the concept of the citizen that gave rise in the Kaye Scholer case to the conflict regarding the appropriate role of the lawyer. The Comment concludes by exploring some normative questions raised by the OTS regulatory scheme.

\section{INTRODUCTION}

The failure of numerous savings and loan institutions in the $1980 \mathrm{~s}^{1}$ has led to claims against lawyers and other professionals who advised those

Copyright @ 1994 Califomia Law Review, Inc.

$\dagger$ B.A. 1991, University of Portland; J.D. candidate 1994, Boalt Hall School of Law, University of California, Berkeley.

I would like to thank Professor Robert Post for his patient assistance and encouragentent. I also thank my nıother, Marjorie Amoury, nıy father, Robert J. Amoury, and nıy grandnother, Catherine Hero, for all their support during law school; Flavio Rose for his careful, thoughtful editing; Jesse Combs for his unique and special encouragentent; and especially niy husband Bruce, without whose love and support this Comment would not have been written.

1. During the 1980 s the savings and loan industry experienced its worst performance in its 160-year existence. Over the period 525 insolvent institutions were liquidated or sold at an estimated present-value cost . . of $\$ 47$ billion. Another eighteen institutions were simply stabilized ... a at an estimated present-value cost of $\$ 7$ billion. Despite all these closures, still 
institutions. ${ }^{2}$ The most expensive thrift failure of the decade was that of Charles Keating's Lincohı Savings and Loan, which reportedly cost the federal government more than two billion dollars. ${ }^{3}$ As a result of that failure, on March 1, 1992, the Office of Thrift Supervision (OTS) filed a $\$ 275$ million enforcement action against Kaye, Scholer, Fierman, Hays and Handler (Kaye Scholer), one of the law firms that represented Lincoln. OTS also issued a temporary cease and desist order freezing the firm's assets and the personal assets of three Kaye Scholer partners. OTS charged Kaye Scholer with violating several OTS regulations and claimed that the violations substantially increased losses to the thrift and the federal insurance fund. Six days after OTS filed its Notice of Charges, Kaye Scholer settled the case for $\$ 41$ million. ${ }^{4}$

The Kaye Scholer case generated enormous controversy in the legal community. ${ }^{5}$ Critics of OTS maintained that OTS sought to impose duties on Kaye Scholer that conflict with professional ethics rules. ${ }^{6}$ These critics argued that OTS is trying to redefine the role of the lawyer:

This Comment evaluates that claim and concludes that OTS regulations do impose obligations on lawyers that conflict with traditional legal ethics rules. The OTS system of regulation does contemplate a different role for the lawyer than that which grows out of the adversary system. The Comment goes on to suggest, however, that this conflict over professional responsibility reflects a more fundamental conflict. It is the thesis of this Comment that the Kaye Scholer matter involves not merely the role of the lawyer, but, more fundamentally, the role of the citizen and the citizen's

another 517 institutions were reporting insolvency but were still operating at the end of the decade.

James R. Barth, The Great Savings and Loan Debacle 1 (1991).

2. Between 1989 and 1992 , the government recovered $\$ 1.7$ billion from claims against professional advisers associated with failed banks and thrifts. Howell E. Jackson, Reflections on Kaye, Scholer: Enlisting Lawyers to Improve the Regulation of Financial Institutions, 66 S. CAL. L. RBv. 1019, 1023 n.12 (1993).

3. Stephen Gillers \& Roy D. Simon, JR., Regulation of Lawyers: Statutes and STANDARDS 729 (1993).

4. For an in-depth discussion, see infra Part II.

5. For just a sampling of the cominentary, see, for example, GILIERs \& SimoN, supra note 3, at 729-78; Robert G. Day, Note, Administrative Watchdogs or Zealous Advocates? Implications for Legal Ethics in the Face of Expanded Attorney Liability, 45 STAN. L. REv. 645 (1993); Susan Beck \& Michael Orey, They Got What They Deserved, AM. LAw., May 1992, at 68; Edward Brodsky, The 'Kaye Scholer' Case, N.Y. L.J., May 22, 1992, at 1; Stephanic B. Goldberg, Welcome to the New Uncertainty, A.B.A. J., July 1992, at 51; Geoffrey C. Hazard, Ethics, NAT'L L.J., Apr. 27, 1992, at 15. Additionally, Southem California Law Review recently published a symposium, In the Matter of Kaye, Scholer, Fierman, Hays and Handler: A Symposium on Government Regulation, Lawyers' Ethics, and the Rule of Law, 66 S. CAL. L. Rev. 977 (1993).

6. See Lester Brickman, Has the Office of Thrift Supervision Changed the Relevant Ethics Rules by its Actions in the Kaye, Scholer Matter, in The Attorney-Client Relationship AfTER Kayb, SCHOLER 79 (PLI Corporate Law \& Practice Course Handbook Series No. 779, 1992); James Podgcrs, Changing the Rules, A.B.A. J., July 1992, at 53; Kaye, Scholer and the New Ethics Imperative, AM. LAw., Sept. 1992, at 64. 
relationship with the state. The Kaye Scholer controversy reflects a struggle between two different conceptions of what it means to be a citizen.

Part I describes OTS's statutory and regulatory scheme, and Part II describes the Kaye Scholer litigation. Part III examines the traditional role of the lawyer that grows out of the adversary system, and with that information, Part IV concludes that the obligations OTS seeks to impose on lawyers are in tension with the professional ethics rules that inform the lawyer's traditional role.

This much is not surprising, given the furor in the legal community over OTS's actions. Thus, Part V looks beyond the legal ethics rules and the role of the lawyer to explore the conception of the citizen that underlies the adversary system. Part V begins by observing that our democratic form of government is premised ou the notion that citizens are autonomous. The section goes on to suggest that the adversary system embodies this same concept of the autonomous citizen. Both the adversary system and the role of the lawyer that grows out of it reflect the belief that citizens have independent interests and goals that the state must take into account when regulating the citizen's activities.

Part VI suggests that the OTS" system embodies a different vision of the citizen. The OTS system is structured to achieve its regulatory goals by the most efficient means possible. The OTS system does not view the thrifts it regulates as autonomous citizens who have independent objectives. Rather, the OTS system locates the thrifts within OTS's instrumental orientation. The OTS system defines the role of thrifts in terms of OTS's regulatory goals and manipulates the thrifts according to those goals.

It is not surprising, then, that the OTS system and the adversary system construct different roles for lawyers. The ethical obligations that we have traditionally placed on lawyers are based in large part on the presumption of citizen autonomy that underlies the adversary system. When we change the concept of the citizen upon which a legal system is based, the role of the lawyer will also change. Part VII concludes the Comment by touching on some normative questions about the OTS system. While it is beyond the scope of this Comment to evaluate the desirability of the OTS system in any detail, Part VII examines several considerations that may be relevant to such an inquiry.

THE OTS SYSTEM

\section{A. Events Leading to the Establishment of OTS}

The Federal Home Loan Bank Board (FHLBB), established in 1932, was for many years the federal regulatory authority for savings and loan 
institutions (S\&Ls). ${ }^{7}$ In 1989, however, Congress enacted the Financial Institutions Reform, Recovery and Enforcement Act (FIRREA) ${ }^{8}$ to address the failures of federally insured S\&Ls. ${ }^{9}$ FIRREA abolished the FHLBB and created OTS ${ }^{10}$ to take over many of its functions. The following two sections briefly discuss the S\&L crisis and FIRREA, the legislation born of the crisis.

\section{The S\&L Crisis}

The collapse of many of America's savings and loan institutions in the 1980s led to a staggering financial crisis. Between 1980 and 1991, over a thousand S\&Ls failed-more than seven times as many as in the previous forty-six years. ${ }^{11}$ The causes of the S\&L crisis are complex and controversial. ${ }^{12}$ A partial list of contributing factors includes: (1) poorly timed federal deregulation; (2) thrift mismanagement; (3) inadequate oversight, supervision, and regulation by federal regulatory agencies and the Reagan administration; (4) economic collapse in the Southwest; (5) radical deregulation by several large states; and (6) insider abuse and fraud. ${ }^{13}$ In this section I will focus on federal deregulation, inadequate supervision, and the FHLBB's contribution to these problems.

7. Carter H. Golembe \& David S. Holland, Federal Regulation of Bankino 1983-84, al 186 (1983). Kaye Scholer's dealings with the FHLBB gave rise to OTS's enforcement action. U.S.C.).

8. Pub. L. No. 101-73, 103 Stat. 183 (1989) (codified primarily in scattcred sections of 12

9. Paul v. OTS, 763 F. Supp. 568, 571 (S.D. Fla. 1990), aff'd without opinion sub nom. Paul v. Ryan, 948 F.2d 1297 (11th Cir. 1991).

10. FIRREA placed OTS within the Treasury Department. FIRREA sec. 301, § 3(a), 103 Stat. at 278 (codified at 12 U.S.C. \$ 1462a(a)). "The placement of the OTS within the Treasury was considered quite important since the Congress believed that the OTS would thereby be less susceptible to lobbying from the thrift industry or to pressures from individual Congressmen and Senators ...." LAwRzNCB J. White, The S\&L Debacle: Public Poljcy Lessons for Bank and Thrift Regulation 182 (1991).

11. From 1934 through 1979, a 46-year period, 143 S\&Ls failed, costing the insurance fund $\$ 306$ million. From 1980 througb 1991, a 12-year period, 1073 S\&Ls failed, costing $\$ 119$ billion. U.S. GzN. Accounting Office, Report to Congressional Committees, Bank and Thrift Reoulation: Improvements NeEded in Examination Qualrty and Regulatory StruCture 8 (1993).

An S\&L fails when its assets, such as loans and portfolio investments, become worth less than its liabilities, which are mainly insured deposits. See WHrTE, supra note 10, at 36-38. Although it is difficult to generalize, $S \& L s$ typically failed because many of their loans and investments lost value, for example when borrowers failed to repay loans. Excessive operating expenses often aggravated the problem. See id. at 118-19.

12. For a more detailed discussion of the history and the collapse of the S\&L industry, see generally Barth, supra note 1; Ned Eichler, The Thrift Debacle (1989); Martin Mayer, The Greatest-Ever Bank Robbery: The Collapse of the Savings and LoAn INDUSTRY (1990); Stephen Pizzo et al., Inside Job: The Lootno of America's Savings and Loans (1989); Whrte, supra note 10; Carl Felsenfeld, The Savings and Loan Crisis, 59 FordHAM L. Rev. S7 (1991); Robert J. Laughlin, Note, Causes of the Savings and Loan Debacle, 59 Fordham L. Rev. S301 (1991).

13. H.R. Rep. No. 54, 101 st Cong., 1st Sess., pt. 1, at 294 (1989), reprinted in 1989 U.S.C.C.A.N. 86,90 . 


\section{a. Federal Deregulation}

A number of federal statutes contributed to the deregulation of the savings and loan industry. ${ }^{14}$ The Financial Institutions Regulatory and Interest Rate Control Act of $1978^{15}$ partially increased the ceiling on federal depository insurance. ${ }^{16}$ The Depository Institutions Deregulation and Monetary Control Act of $1980^{17}$ phased out interest rate caps on bank and thrift deposits; ${ }^{18}$ raised federal deposit insurance coverage from $\$ 40,000$ to $\$ 100,000 ;{ }^{19}$ and permitted S\&Ls to offer negotiable order of withdrawal (NOW) accounts. ${ }^{20}$ The Garn-St Germain Depository Institutions Act of $1982^{21}$ allowed S\&Ls to offer money market accounts, ${ }^{22}$ to engage in agricultural and commercial lending (including commercial real estate lending), ${ }^{23}$ and to accept demand deposits. ${ }^{24}$ It also permitted S\&Ls to make more consumer loans, ${ }^{25}$ and it increased the amounts of loans that depository institutions could make to one borrower. ${ }^{26}$

\section{b. Inadequate Supervision}

At the same time that Congress was granting S\&Ls broader investment and lending powers, the federal government was reducing its regulatory supervision over S\&Ls. ${ }^{27}$ During the Reagan presidency, the Treasury Department and the federal thrift regulatory agencies continually pressured Congress to limit government intervention in the financial services industry. ${ }^{28}$ Notably, the Reagan admimistration refused to increase the number of savings and loan examiners even though the thrift industry was going

14. For a more detailed account of the savings and loan deregulation, see Nicholas A. LASH, Banking Laws and Regulations: An Economic Perspective 17-21 (1987); White, supra note 10, at $67-87$.

15. Pub. L. No. 95-630, 92 Stat. 3641 (1978) (codified primarily in scattered sections of 12 U.S.C.).

16. Id. § 1401, 92 Stat. at 3712-13 (amending 12 U.S.C. $\S \S 1821$ (a), 1728(d), 1787(c)).

17. Pub. L. No. 96-221, 94 Stat. 132 (1980) (codified primarily in scattered sections of 12 U.S.C.).

18. Id. $\S \S 201-210,94$ Stat. at $142-45$.

19. Id. $\S 308,94$ Stat. at $147-48$.

20. Id. $\S 303,94$ Stat. at 146 (amending 12 U.S.C. $\S 1832(a)$ ).

21. Pub. L. No. 97-320, 96 Stat. 1469 (1982) (codified primarily in scattered sections of 12 U.S.C.).

22. Id. $\S 327,96$ Stat. at 1501 (amending 12 U.S.C. § 3503).

23. Id. $\S \S 322,325,96$ Stat. at 1499,1500 (amending 12 U.S.C. $\S 1464(c)(1)$ ).

24. Id. § 312, 96 Stat. at 1496-97 (amending 12 U.S.C. § 1464(b)).

25. Id. § 329, 96 Stat. at 1502 (amending 12 U.S.C. $\S 1464(\mathrm{c})(2)(B)$ ).

26. Id. $\S 401,96$ Stat. at 1508-09 (amending 12 U.S.C. $\$ 84$ ). These lending limits applied by their terms only to national banks. However, a different section of the Garn-St Germain Act extended them to commereial loans made by S\&Ls. Id. $\S 325,96$ Stat. at 1500 (amending 12 U.S.C. $\S 1464(c)(1))$.

27. Paul T. Clark et al., Regulation of Savings Associations Under the Financial Institutions Reform, Recovery, and Enforcement Act of 1989, 45 Bus. LAw. 1013, 1022 (1990).

28. H.R. Rep. No. 54, supra note 13, at 301, reprinted in 1989 U.S.C.C.A.N. at 97. 
through its most significant restructuring since the Great Depression. ${ }^{29}$ By the mid-1980s, even the FHLBB's top management understood that more examiners were needed. Yet, the administration ignored the FHLBB's repeated requests for more resources. ${ }^{30}$

\section{c. Conflict of Interest in the FHLBB}

The FHLBB had conflicting responsibilities which contributed to the S\&L crisis. ${ }^{31}$ The FHLBB was responsible for chartering, examining, and supervising federal savings associations, ${ }^{32}$ administering the depository insurance obligations of the Federal Savings and Loan Insurance Corporation (FSLIC), ${ }^{33}$ and supervising the Federal Home Loan Banks in the provision of credit and other services to savings associations. ${ }^{34}$ The FHLBB, then, as administrator of the FSLIC, was charged with protecting the industry's insurance fund. ${ }^{35}$ However, it also considered itself an industry promoter. ${ }^{36}$ Witnesses testifying before the House Banking Committee asserted that the Board's primary goal was to promote the thrift industry, often at the expense of the deposit insurance fund. ${ }^{37}$ The FHLBB pursued this goal by relaxing capital standards and failing to bring enforcement actions against thrift operators. ${ }^{38}$

\section{FIRREA}

In response to the S\&L crisis, Congress enacted the Financial Institutions Reform, Recovery, and Enforcement Act (FIRREA) in 1989.39 Congress was convinced that insufficient enforcement powers and inade-

29. Id. "[T] he number of the field-force thrift examiners and supervisors were [sic] actually reduced between 1981 and 1984 . . . Further, the numbers of examinations (audits) of thrifts were substantially reduced between 1980 and 1983 and rose only slightly in 1984." WHITE, supra note 10, at 88 (including tables detailing the reduction in the FHLBB's staff and resources).

30. H.R. REP. No. 54, supra note 13, at 301, reprinted in 1989 U.S.C.C.A.N. at 97.

31. Id. at 302, reprinted in 1989 U.S.C.C.A.N. at 98.

32. 12 U.S.C. $\$ 1464$ (a) (1988).

33. 12 U.S.C. $\$ 1726($ a) (1988) (repealed 1989).

34. 12 U.S.C. $\$ 1437$ (1988) (repealed 1989).

35. H.R. REP. No. 54, supra note 13, at 302, reprinted in 1989 U.S.C.C.A.N. at 98.

36. Id. For instance, the FHLBB, as the chartering authority of a federal savings association, had the authority to declare the savings association insolvent. However,

the [FHLBB], as the operating head of the FSLIC, had a conflicting interest of minimizing the number of savings associations that were declared insolvent because insolvencies would deplete the insurance reserves of the FSLIC. Similarly, the [FHLBB], as administrative head of the Federal Home Loan Banks, had an interest in ensuring that the Federal Home Loan Banks only made advances to creditworthy savings associations; but at the same time it had an interest, as operating head of the FSLIC, in maximizing the availability of funds to financially troubled savings associations.

Clark et al., supra note 27, at 1023 n.91.

37. H.R. REP. No. 54, supra note 13, at 302, reprinted in 1989 U.S.C.C.A.N. at 98.

38. Id.

39. Pub. L. No. 101-73, 103 Stat. 183 (1989); see U.S. GEN. Accountno OfFCE, supra note 11, at 3. For a more eomprehensive diseussion and critique of FIRREA, see BARTH, supra note 1, at 79-99; WHITE, supra note 10 , at $175-93$. 
quate enforcement efforts contributed heavily to numerous thrift and bank failures. ${ }^{40}$ Believing that a massive increase in enforcement powers was imperative, Congress swept aside objections from industry representatives and conferred on federal banking regulators "the most extensive array of administrative sanctions ever possessed by American administrative agencies." ${ }^{21}$ Further, in response to the conflict of interest concerns discussed above, FIRREA abolished the FHLBB ${ }^{42}$ and allocated its conflicting functions to three separate bodies: the Office of Thrift Supervision, the Federal Deposit Insurance Corporation, and the Federal Housing Finance Board. ${ }^{43}$

Since FIRREA, Congress has strengthened the power of bank regulators further by enacting the Comprehensive Thrift and Bank Fraud Prosecution and Taxpayer Recovery Act of $1990^{44}$ and more recently the FDIC Improvement Act of 1991.45

\section{B. The Office of Thrift Supervision}

FIRREA established OTS to serve as the primary regulator of approximately 2600 federal and state-chartered thrifts. ${ }^{46}$ "OTS carries out that responsibility by adopting regulations governing the savings and loan industry, by examining and supervising thrift institutions and their affihates, and by taking whatever action is necessary to enforce their compliance with federal laws and regulations."

40. See H.R. Rep. No. 54, supra note 13, at 464-65, reprinted in 1989 U.S.C.C.A.N. at 260-61; see also S. Rep. No. 19, 101st Cong., 1st Sess. 5 (1989).

41. Lawrence G. Baxter, Judicial Responses to the Recent Enforcement Activities of the Federal Banking Regulators, 59 FordhaM L. Rev. S193, S201-02 (1991). Baxter continued: "To prove that Congress was serious, the relevant legislative provisions were accompanied by exhortations from Congress to deploy these new powers to the maximum extent feasible." Id. at S203. For example, the conference report on FIRREA stated that "the Conferees intend for the Federal banking agencies to aggressively utilize this new authority." H.R. Conf. Rep. No. 222, 101st Cong., 1st Sess. 440 (1989), reprinted in 1989 U.S.C.C.A.N. 432, 479.

42. Pub. L. No. 101-73, § 401(a)(2), 103 Stat. 183, 354 (1989).

43. 12 U.S.C. § 1422(a) (Supp. IV 1992) (directing the Federal Housing Finance Board to supervise the Federal Home Loan Banks); id. § 1463(a)(1) (directing OTS to examine and regulate thrifts); id. $\$ 1811$ (directing the FDIC to insure deposits in thrifts).

For the argument that FIRREA did not solve the conflict of interest problems because it did not "recognize that federal regulators have incentives to keep insolvent institutions open," see Jonathan $R$. Macey \& Geoffrey P. Miller, Kaye, Scholer, FIRREA, aud the Desirability of Early Closure: A View of the Kaye, Scholer Case from the Perspective of Bank Regulatory Policy, 66 S. CAL. L. Rev. 1115, 1135 (1993). Macey and Miller maintain that federal deposit insurance and the bizarre criteria by which banking agencies are evaluated create "strong incentives for regulators to delay closing insolvent financial institutions. In fact, banking regnlators have strong incentives to delay identifying problem banks, to deny the severity of the banking crisis generally, and to postpone meaningful action for as long as possible regardless of the cost." Id. at 1133 .

44. Pub. L. No. 10I-647, 104 Stat. 4859 (1990) (codified primarily in scattered sections of 12 \& 18 U.S.C.).

45. Pub. L. No. 102-242, 105 Stat. 2236 (1991) (codified primarily in scattered sections of 12 U.S.C.).

46. Federal Regulatory Directory 843 (6th ed. 1990).

47. Id. 


\section{Persons Over Whom OTS has Power}

FIRREA broadened the scope of persons who are subject to regulatory control. FIRREA abolished the old list of individual targets ${ }^{48}$ and replaced them with the new term "institution-affiliated party." 49 An institution-affiliated party is broadly defined to include, among others, any shareholder, consultant, or joint venture partner who participates in the conduct of the association's affairs, and any independent contractor, such as an attorney, appraiser, or accountant, who knowingly or recklessly participates in a violation of any law, regulation, breach of fiduciary duty or unsafe or unsound practice that caused or is likely to cause more than a minimal financial loss to a federally insured thrift. ${ }^{50}$

In addition, prior to FIRREA, the FHLBB could initiate enforcement proceedings only against persons who were still associated with the thrift. ${ }^{51}$ By contrast, OTS can proceed agamst an institution-affiliated party even if that party resigns, is fired, or beconies otherwise separated fron the thrift, so long as notice of the action is served within six years from the time of the individual's separation. ${ }^{52}$

\section{OTS Oversight of $S \& L$ Management}

FIRREA gave OTS broad oversight powers over the thrift industry. Thrifts must notify OTS at least thirty days before adding a "senior executive officer" if the thrift has been chartered for less than two years, has undergone a change in control within the preceding two years, or is undercapitalized or otherwise in a "troubled condition." 53 OTS may reject the addition within thirty days of receiving notice from the association. ${ }^{54}$

OTS also has broad powers to remove or suspend institution-affiliated parties. OTS may remove an institution-affiliated party from office and prohibit that person from ever participating in the affairs of any federally insured institution. ${ }^{55}$ While waiting for a final order of removal or prohibi-

48. Under earlier statutes, the FHLBB could issue cease and desist orders against, among others, any person participating in the conduct of the affairs of the association if the FSLIC determincd that the person (i) had or was engaged in unsafe or unsound practices in conducting the business of the association, or (ii) had violated or was violating any law, regulation, written condition imposed by the FSLIC in connection with the approval of an application or other request by the association, or written agreement entered into between the association and the FSLIC. 12 U.S.C. $\$ 1464$ (d)(2)(A) (1988) (amended 1989).

49. 12 U.S.C. $\S 1813(u)$ (Supp. IV 1992).

50. Id. \&1813(u)(3), (4).

51. 12 U.S.C. $\$ 1730(\mathrm{e})-(\mathrm{g})(1988)$ (repealed 1989).

52. 12 U.S.C. \& $1818(\mathrm{i})(3)$ (Supp. IV 1992).

53. Id. \$ 1831i(a). OTS has proposed a rule that defines "senior executive officer" expansively to include an institution's general counsel and any non-employee retained to perform similar functions. 56 Fed. Reg. 37,162 (Aug. 5, 1991).

54. 12 U.S.C. $\$ 1831$ i(b) (Supp. IV 1992).

55. Id. $\S 1818(\mathrm{e})$. OTS must show that the institution-affiliated party (1) violated a law, regulation, final cease-and-desist order, or written agreement or condition, or engaged in an unsafe or unsound practice in connection with any insured depository institution or business institution, or has 
tion, OTS may temporarily suspend an institution-affiliated party if it believes that a suspension is necessary to protect the institution or its depositors. $^{56}$ OTS may also immediately suspend any institution-affiliated party who has been charged under federal or state law with a crime involving dishonesty or breach of trust. ${ }^{57}$ Even if the party is eventually acquitted, OTS may still remove him using its general removal power. ${ }^{58} \mathrm{~A}$ person who is removed, prohibited, or suspended is precluded from participating in any manner in the affairs of any federally insured depository institution. ${ }^{59}$

\section{OTS Access to Information}

In order to regulate effectively, OTS needs information about a thrift's practices. " 'Unfettered access, including the ability to appear at [a thrift] without advance notice, is essential to the fulfillment of [the regulators'] function." "60 This section will discuss two of OTS's most effective means of gaiming information: exanninations and disclosure requirements.

\section{a. Examinations}

OTS carefully monitors all aspects of a thrift's practice by conducting periodic, comprehensive examinations. ${ }^{61}$ OTS may examine a thrift at any time, without giving it advance notice, ${ }^{62}$ and the thrift must pay the costs of the examination. ${ }^{63}$ Moreover, in order for OTS to examine the thrift thoroughly and efficiently, the thrift must

establish and maintain such accounting and other records as will provide an accurate and complete record of all busimess it transacts, and the documents, files, and other nraterial or property comprising said records shall at all times be available for such examination and

breached a fiduciary duty; and (2) that the violation, practice, or breach has caused or probably will cause a financial loss to the institution, has prejudiced or could prejudice the depositors' interests, or has produced a pecuniary gain or other benefit to the institution-affiliated party; and (3) that the violation, practice or breach either involves personal dishonesty or demonstrated "willful or continuing disregard" for the safety or soundness of the institution. Id. $\S 1818(\mathrm{e})(1)$.

56. Id. $\S 1818(\mathrm{e})(3)$. The respondent may seek a judicial stay of the suspension order by applying to the appropriate United States District Court within ten days after service of the suspension order. Id. $\S 1818(\mathrm{f})$.

57. Id. $\$ 1818(\mathrm{~g})(1)$. OTS must still make a determination that the individual's continued participation poses a threat to the interests of the creditors or threatens public confidence in the institution. However, unlike $\S 1818(\mathrm{e}), \S 1818(\mathrm{~g})(1)$ does not provide for district court jurisdiction to stay the suspension.

58. Id. $\S 1818(\mathrm{~g})(1)(\mathrm{D})(\mathrm{ii})$.

59. Id. $\S 1818(\mathrm{e})(7)$.

60. Beek \& Orey, supra note 5, at 70 (quoting a 1986 letter from B.J. Davis, FHLBB director for examinations in San Francisco, to Kaye Scholer partner Peter Fishbein).

61. 12 C.F.R. $\$ 563.170$ (a) (1993). For a more detailed description of bank and thrift examinations, see U.S. GEN. AcCountra OFFCE, supra note 11, at 19-20.

62. 12 C.F.R. $\$ 563.170$ (a) (1993).

63. Id. 
audit wherever any of said records, documents, files, material, or property may be. ${ }^{64}$

Thrifts must also notify OTS before moving any records from a home office to a branch office. ${ }^{65}$

To ensure compliance with its examination requirements, OTS may impose a civil money penalty on thrifts that refuse to allow an examination or that refuse to provide information that must be disclosed during an examination. ${ }^{66}$ Moreover, if the thrift's records are incomplete or inaccurate in a way that prevents OTS from ascertaining the thrift's financial condition or determining the details of any fiuancial transaction, OTS may issue a temporary cease and desist order requiring the thrift to cease any activity or practice giving rise to the incomplete or inaccurate books. ${ }^{67}$

\section{b. Disclosure Requirements}

OTS's disclosure requirements, like its examination requirements, enable OTS to monitor thrifts' practices. Thrifts must periodically provide reports to OTS. ${ }^{68}$ OTS prescribes the timing and manner of the reports. ${ }^{69}$ Thrifts and institution-affiliated parties must not make oral or written statements to OTS that are misleading as to material facts, or that omit any material facts concerning any matter within OTS's jurisdiction. ${ }^{70}$

OTS highly values candid disclosure. Accordingly, when setting fines for violations, OTS regulators consider the thrift's practice of disclosure. Circumstances indicating that the thrift concealed the offending conduct may result in an enhanced penalty, while cooperation with regulators is considered a mitigating factor. ${ }^{71}$ OTS penalties, then, are designed not only to induce thrifts to obey OTS's substantive rules, but also to encourage thrifts to assist OTS by disclosing all relevant infornıtion.

In summary, OTS regulations require thrifts to provide full access to government examiners. ${ }^{72}$ Thrifts can have no secrets from the regulators.
64. Id. $\S 563.170(\mathrm{c})$.
65. Id. §563.170(d).
66. 12 U.S.C. § 1467(d) (Supp. IV 1992).
67. Id. $\S 1818(\mathrm{c})(3)(\mathrm{A})(\mathrm{i})$.
68. 12 C.F.R. § 563.180(a) (1993).
69. Id.
70. Id. $\S 563.180(\mathrm{~b})(1)$. .

71. Michael S. Helfer \& Stuart Cane, Enforcement Actions Against Banks and Thrifts, in Limgating For and AganNst the FDIC and the RTC 1992, at 83, 125 (PLI Commercial Law \& Practice Course Handbook Series No. 625, 1992).

72. "[T]he applicable statutes and regulations give federal officials a virtually unlimitcd right to inspect thrift practices ...." David B. Wilkins, Making Context Count: Regulating Lawyers After Kaye, Scholer, 66 S. CAL. L. Rev. 1145, 1176 (1993). 


\section{Enforcement Mechanisms Available to OTS}

OTS has numerous mechanisms for enforcing its regulations. Some of the most important are cease and desist orders, temporary cease and desist orders, civil money penalties, capital directives, and thrift receiverships.

\section{a. Cease and Desist Orders}

OTS may issue a cease and desist order on the grounds that: (i) the respondent is engaging or has engaged, or there is reasonable cause to beheve that the respondent is about to engage, $m$ any unsafe or unsound practice in conducting the business of the institution; or (ii) the respondent is violating, or has violated, or there is reasonable cause to believe that the respondent is about to violate, any law, rule, regulation, or written agreement with OTS. ${ }^{73}$ OTS commences a cease and desist order by filing a Notice of Charges. ${ }^{74}$ Upon receiving the Notice of Charges, the respondent may either consent to the order or appear at an administrative hearing to contest the charges. ${ }^{75}$ An administrative law judge (ALJ), employed by OTS, presides over the hearing. ${ }^{76}$ ALJs are Article I judges who do not have the salary protection and life tenure that Article III judges enjoy. ${ }^{77}$

The ALJ receives evidence and can rule on some motions; however, only the Director of OTS has the power to decide motions to dismiss the proceeding or other motions that result in a final determination of the merits of the proceeding. ${ }^{78}$ After hearing the evidence, the ALJ makes findings of fact and conclusions of law, and issues a recommendation to OTS. ${ }^{79}$.

The Director of OTS has substantial discretion to adopt, reject, or modify the ALJ's recommendation. ${ }^{80}$ If the Director finds that the record made at the administrative hearing estabhishes the violation described in its Notice of Charges, then OTS may issue the cease and desist order. The cease and desist order will become effective in thirty days unless it is set aside before that time by OTS or a reviewing court. ${ }^{81}$

The respondent may seek judicial review of the order in a federal court of appeals within thirty days. ${ }^{82}$ The scope of the review is governed by Chapter 7 of the Administrative Procedure Act (APA). ${ }^{83}$ Accordingly, the court must sustain OTS's findings if they are supported by substantial evi-

73. 12 U.S.C. § 1818(b)(1) (Supp. IV 1992).

74. Id.

75. Id.

76. 12 U.S.C. $\$ 1818(\mathrm{~h})(1)$ (Supp. IV 1992) provides for hearings pursuant to the Administrative Procedure Act, 5 U.S.C. $\$ \S 551-706$ (1988 \& Supp. IV 1992).

77. GLlers \& Simon, supra note 3, at 730.

78. 12 C.F.R. $\S 509.5(b)(7)(1993)$.

79. Id. $\S 509.38$.

80. See, e.g., id. $\S \S 509.4,509.39,509.40$; Central Nat'l Bank v. United States Dep't of Treasury, 912 F.2d 897, 904-05 (7th Cir. 1990).

81. 12 U.S.C. \& 1818(b)(1)-(2) (Supp. IV 1992).

82. Id. $\S 1818(\mathrm{~h})(2)$.

83. 5 U.S.C. $\$ 706$ (1988). 
dence in the record as a whole. ${ }^{84}$ And the court will not disturb OTS's choice of remedy unless it is an abuse of discretion or otherwise arbitrary or capricious. ${ }^{85}$

\section{b. Temporary Cease and Desist Orders}

OTS also has the authority to issue temporary cease and desist orders whenever it determines that the conduct specified in its Notice of Charges is likely to dissipate the thrift's assets or earnings sigmificantly, or is likely to weaken the thrift's condition or otherwise prejudice the interests of depositors before the permanent cease and desist proceedings can be completed ${ }^{86}$ Such orders may require the respondent to take affirmative steps to prevent or remedy any insolvency, dissipation, condition, or prejudice pending the completion of the permanent cease and desist proceedings. ${ }^{87}$ Temporary cease and desist orders are effective immediately upon service without a prior hearing. ${ }^{88}$ The controversial Kaye Scholer "asset freeze" was accomplished by means of a temporary cease and desist order. ${ }^{89}$

A party served with a temporary cease and desist order has ten days to apply to a United States District Court for an injunction setting aside, limiting, or suspending the order. ${ }^{90}$ The chances of getting the order overturned, however, are remote because OTS must meet only a mimmal standard of proof to justify the order. ${ }^{91}$ For instance, in Parker v. Ryan ${ }^{92}$ the Fifth Circuit, in upholding an OTS temporary cease and desist order, ${ }^{93}$ endorsed OTS's contention that a temporary order is judicially enforceable if OTS can present "a prima facie case of illegality, based upon the agency's demonstrated compliance with its procedures and [with] the statutory

84. Akin v. OTS, 950 F.2d 1180, 1183 (5th Cir. 1992) (applying 5 U.S.C. § 706(2)).

85. Id. " "The assessment of a penalty is particularly delegated to the [director]. The choice then of a sanction is not to be overturned unless "it is unwarranted in law" or "without justification in fact." " " Id. (quoting Butz v. Glover Livestock Comm'n Co., 411 U.S. 182, 185-86 (1973)); see also Del Junco v. Conover, 682 F.2d 1338, 1340 (9th Cir. 1982), cert. denied, 459 U.S. 1146 (1983).

86. 12 U.S.C. $\$ 1818$ (c)(1) (Supp. IV 1992). Prior to FIRREA, the FHLBB had to make a greater showing in order to issue a temporary cease and desist order. The FHLBB was required to show that the association or a person participating in the affairs of the association was engaged in an unsafe or unsound practice, the continuation of which was likely to cause insolvency or "substantial" dissipation of the association's assets. 12 U.S.C. $\$ 1464(\mathrm{~d})(3)(\mathrm{A})$ (1988) (amended 1989); id. § 1730(f)(1) (repealed 1989).

87. 12 U.S.C. § 1818(c)(1) (Supp. IV 1992).

88. Id.

89. See Goldberg, supra note 5, at 51.

90. 12 U.S.C. $\S 1818$ (c)(2) (Supp. IV 1992).

91. Since 1990 OTS has issued 21 temporary cease and desist orders. Courts have upheld OTS's exereise of its discretion in all but one of the cases in which the orders were challenged. Harris Weinstein et al., Asset Preservation Orders by the Office of Thrift Supervision, in EMERoino Issues in THE "NEw" BusINESS OF BANKINo 447, 453 (PLI Commercial Law \& Practiee Course Handbook Series No. A-637, 1992) [hereinafter EMERoino Issues].

92. 959 F.2d 579 (5th Cir. 1992).

93. The order prohibited Parker from disposing of any funds or assets other than ordinary household expenditures of less than $\$ 5000$ and required him to post seeurity in an amount exceeding $\$ 13$ million (reduced by OTS to $\$ 100,000$ during the district court enforcement proceedings). Id. at 581-82. 
grounds for issuing a temporary order." 94 The only evidence OTS has to provide as part of its prima facie case is "a verified statement of the specific facts giving rise to violations or improprieties."95 The court also held that Parker was not entitled to an evidentiary hearing in the district court unless he disputed a fact material to OTS's prima facie case. ${ }^{96}$ OTS, then, can freeze the assets of institution-affiliated parties without prior judicial approval. ${ }^{97}$ Courts have upheld such orders against due process challenges, reasoning that the availability of judicial review within ten days after the issuance of the order is constitutionally adequate. ${ }^{98}$

\section{c. Civil Money Penalties}

FIRREA dramatically increased the occasions for and the amounts of civil money penalties that can be imposed on thrifts and institution-affiliated parties. ${ }^{99}$ OTS sends a written notice of a civil money penalty, ${ }^{100}$ and then the respondent must request an administrative hearing within twenty days, or else the assessment becomes a final and unappealable order. ${ }^{101}$ Judicial review of civil money penalties is also governed by the APA. ${ }^{102}$ Thus, courts are "limited to determining whether the agency substantially complied with statutory and regulatory procedures, whether substantial evidence supports its factual determinations, and whether its action was an abuse of discretion." 103

94. Id. at 583.

95. Id.

96. Id. at 584; cf. Landmark Land Co. v. OTS, 990 F.2d 807, 812 (5th Cir. 1993) (requiring an evidentiary hearing because "the record reveals several disputes of material fact that the district court must necessarily resolve").

97. See, e.g., Spiegel v. Ryan, 946 F.2d 1435 (9th Cir. 1991) (upholding OTS temporary order requiring Spiegel to pay $\$ 21$ million in restitution within twenty-four hours of the order's issuance, or face daily-accruing fines), cert. denied, 112 S. Ct. 1584 (1992); Paul v. OTS, 763 F. Supp. 568 (S.D. Fla. 1990) (enforcing an OTS temporary order requiring Paul to post security for an alleged $\$ 30$ million debt owed to his former institution, and requiring prior OTS approval for any transfer of Paul's assets in excess of \$5000), aff'd without opinion sub nom., Paul v. Ryan, 948 F.2d 1297 (11th Cir. 1991).

98. See, e.g., Paul v. OTS, 763 F. Supp. at 572 (due process does not require a predeprivation hearing because OTS actions are a response to an emergency situation); Spiegel, 946 F.2d at 1439-42 (predeprivation hearing not required because OTS action satisfied the three-pronged test of Fuentes v. Shevin, 407 U.S. 67 (1972)); see also Di Stefano v. OTS, 787 F. Supp. 292 (D.R.I. 1992).

99. Baxter, supra note 41 , at $\mathbf{S} 203$.

Prior to FIRREA, the federal banking agencies were generally restricted to imposing civil money penalties on persons who had violated a final cease and desist order, and the maximum civil penalty was $\$ 1000$ for each day the violation continued. FIRREA expanded the grounds upon which the federal banking agencies can assess civil money penalties and jncreased the maximum amount of those penalties. Clark et al., supra note 27, at 1031.

100. 12 U.S.C. $\& 1818(i)(2)(E)$ (i) (Supp. IV 1992).

101. Id. $\S 1818(\mathrm{i})(2)(\mathrm{H}),(\mathrm{E})(\mathrm{ii})$.

102. Id. $\S 1818(\mathrm{~h})(2)$.

103. Burke v. Board of Governors of Fed. Reserve Sys., 940 F.2d 1360, 1365 (10th Cir. 1991), cert. denied, 112 S. Ct. 1957 (1992). 


\section{d. Capital Directives}

OTS establishes minimum levels of capital that thrifts must maintain, and it has two distinct mechanisms for enforcing those minimums. ${ }^{104}$ OTS may treat any failure to maintain the required level of capital as an unsafe or unsound practice, ${ }^{105}$ providing a basis for a cease and desist order. Alternatively, or in addition, OTS may issue a directive requiring the thrift to submit and adhere to an acceptable plan setting forth the "means and timing" by which the thrift intends to comply with the capital requirement. ${ }^{106}$ The "capital directive," and any plan submitted in response, are enforceable to the same extent as a cease and desist order that has become final. ${ }^{107}$

As noted above, OTS may issue a final cease and desist order only after an administrative hearing. ${ }^{108}$ However, even though capital directives have the same legal force as fimal cease and desist orders, the statute authorizing capital directives ${ }^{109}$ does not incorporate the administrative hearing and judicial review provisions of 12 U.S.C. $\S 1818(\mathrm{~h})$, and it does not expressly provide any other mechanisnis for judicial review. After examining the statute, the Fifth Circuit in FDIC v. Bank of Coushatta ${ }^{110}$ held that a capital directive is an agency action "committed to agency discretion by law" for purposes of the Administrative Procedure Act ${ }^{111}$ and is therefore completely unreviewable in the courts. ${ }^{12}$

\section{e. Conservatorship and Receivership Provisions}

OTS may seize a thrift without notice or hearing and place it under conservatorship or into receivership if any of a number of conditions are met. ${ }^{113}$ The thrift may then bring an action in a federal district court requesting that OTS remove the conservator or receiver, and the court "shall upon the merits" dismiss the action or direct the Director to remove the conservator or receiver. ${ }^{114}$ Although courts have differed on their interpretation of the phrase "on the merits," the prevalent practice is for courts to

104. 12 U.S.C. $\S 3907$ (1988).

105. Id. \& 3907(b)(1).

106. Id. § 3907(b)(2). OTS has strictly enforced its capital standards, see Monroe W. Karmin, Oh, that Costly S\&L Mess!: Ineptitude and Turmoil are Driving up the Tab for Taxpayers, U.S. News \& WORLD REP., Apr. 9, 1990, at 37, and it has been careful about approving capital plans. By March 1990. OTS had ruled on 172 capital plans but had approved only 49. Oversight Hearings on the Financial Institutions Reform, Recovery and Enforcement Act of 1989: Hearings Before the Subcomm. on Financial Institutions Supervision, Regulation, and Insurance of the House Comm. on Banking, Finance and Urban Affairs, 101st Cong., 2nd Sess. 486 (1990).

107. 12 U.S.C. $\$ 3907(b)(2)(B)(i i)$ (1988).

108. 12 U.S.C. § 1818(b)(1) (Supp. IV 1992).

109. 12 U.S.C. $\$ 3907$ (1988).

110. 930 F.2d 1122 (5th Cir.), cert. denied, 112 S. Ct. 170 (1991).

111. 5 U.S.C. \& 701(a)(2) (1988).

112. Coushatta, 930 F.2d at 1129 .

113. 12 U.S.C. \& 1464(d)(2)(A) \& (B) (Supp. IV 1992).

114. Id. \& $1464(\mathrm{~d})(2)(\mathrm{B})$. 
review only the administrative record and to uphold the agency's action unless the court finds it to be arbitrary or capricious. ${ }^{115}$

\section{Summary}

In summary, Congress bestowed on OTS wide-ranging and substantial control over all aspects of thrift practice. OTS examines thrifts whenever it chooses, and it requires thrifts to submit regular reports and to volunteer all material facts in those reports. Further, OTS has a number of powerful enforcement mechanisms available and exercises substantial control over the adjudicatory proceedings that result from its enforcement actions. Finally, although most OTS actions are reviewable by a federal court of appeals, the scope of the review is narrow. This background enables us now to examine OTS's litigation with Kaye Scholer.

\section{II}

\section{The Kaye Scholer Controversy}

Charles Keating acquired Lincoln Savings and Loan in 1984. ${ }^{116}$ The FHLBB examined Lincoln in 1986 and identified numerous violations and questionable practices. ${ }^{117}$ Kaye Scholer represented Lincoln in a February 1987 inquiry regarding Lincoln's alleged forgery and backdating of documents. ${ }^{118}$ The FHLBB examined Lincoln again in 1988 and this time identified "aggressive, risk-prone" practices at Lincoln, putting "the continued viability of the association in jeopardy."119 Kaye Scholer again responded to the FHLBB's findings on Lincoln's behalf. ${ }^{120}$ In April of 1989 the FHLBB seized Lincoln. ${ }^{121}$

On March 1, 1992, OTS filed an 83-page Notice of Charges ${ }^{122}$ for a cease and desist order alleging that Kaye Scholer violated numerous FHLBB regulations while representing Lincoln. The Notice of Charges requested restitution of $\$ 275$ million. ${ }^{123}$ At the same time, OTS also filed a temporary cease and desist order ${ }^{124}$ freezing Kaye Scholer's assets and the personal assets of three Kaye Scholer partners. Specifically, the temporary

115. See infra notes $288-296$ and accompanying text.

116. MAYER, supra note 12, at 171. For an interesting account of Charles Keating and Lincoln Savings, see id. at 165-86.

117. Peter M. Fishbein, OTS AP-92-19, paras. 17-18 (Mar. 1, 1992) [hereinafter Notice of Charges]. The OTS orders in the Kaye Scholer matter are reprinted in THE ATTORNEY-CLIENT Relationship AFTER KAYE, Scholer, supra note 6, and in EMERGING 1ssues, supra note 91. The Notice of Charges is also reprinted in GLLERS \& Simon, supra note 3, at 734.

118. Notice of Charges, supra note 117 , para. 19.

119. Id. para. 20.

120. Id. para. 21.

121. Id. para. 5 .

122. Notice of Charges, supra note 117.

123. Id. para. 185 .

124. Peter M. Fishbein, OTS AP-92-20 (Mar. 1, 1992) [hereinafter Temporary Cease and Desist Order]. 
cease and desist order required the firm to escrow $25 \%$ of most partners' shares of firm earnings and to escrow greater percentages of partners Peter Fishbein's and Karen Katzman's earnings. ${ }^{125}$ It required the firm to notify OTS in writing five days before making any expenditures greater than $\$ 50,000 .^{126}$ And it restricted how the firm, its partners, and their families could dispose of their assets. ${ }^{127}$

Broadly speaking, the Notice of Charges made three types of claims. ${ }^{128}$ The first type of claim alleged that the firm's lawyers knowingly and repeatedly misrepresented facts to the FHLBB. Many of the alleged

125. Id. para. 14.b.

126. Id. para. 14.a.

127. Id. para. 16.a. OTS offered few justifications for issuing the temporary cease and desist order against Kaye Scholer. OTS's head counsel, Harris Weinstein, has refused to elaborate officially on why OTS imposed the temporary order. Don J. DeBenedictis, The Big Freeze, A.B.A. J., July 1992, at 58. The order itself states that Fishbein, Katzman, and another partner, Lynn Toby Fisher, "have failed to comply with a subpoena for information about their finances." Temporary Cease and Desist Order, supra note 124, para. 13. The order further alleges that "Kaye Scholer has threatened to amend its professional liability insurance policy so as to impair collectibility of any judgment requiring restitution." Id.

Critics have accused OTS of using the freeze to force Kaye Scholer into a rapid settlement. See Excerpts: Regulators and Lawyers, NAT'L L.J., Apr. 13, 1992, at 10; see also DeBenedictis, supra, at 60 ("Some outsiders charge that the Kaye Scholer freeze was a scare tactic meant to panic other firms the OTS might pursue into settling quickly."). However, Stuart Gerson, head of the Justice Department's civil division, told American Lawyer that OTS ordered the freeze in order to keep the firm from disbanding. Beck \& Orey, supra note 5, at 75. A government official stated that "we necded [Kayc Scholer] to stay together, to continue to make money." Id.

Professors Macey and Miller argue that the freeze order was inappropriate and that OTS "may have lacked statutory authority" to order the freeze when it did. Macey \& Miller, supra note 43, at 1136. They maintain that "[t]he relevant provisions of the statute make it clear that directors, officers, consultants, attorneys, appraisers, and accountants face the prospect of a freeze order only for engaging in activities that are likely to result in adverse effects on insured financial institutions." Id. at 1135. When OTS filed its notice of charges against Kaye Scholer in 1992, the firm's actions could no longer be said to threaten harm to Lincoln's financial position, given that OTS had seized Lincoln three ycars earlier. Id. at 1136.

Although Harris Weinstein has spoken little about the reasons for ordering the freeze, he has shown no such reluctance to defend the scope of the freeze. He has maintained that the order was "crafted to strike a careful balance between the interests of [Kaye Scholer] and the interests of the taxpayers." Harris Weinstein, Remarks at the Pennsylvania Association of Community Bankers (Mar. 23, 1992), in EMERGING Issues, supra note 91, at 391, 401. According to Weinstein, the order permitted the firm to continue its normal financial life while merely requiring the firm to give OTS advance notice of any unusual financial or organizational changes. Id.

128. It is difficult to separate and categorize OTS's claims because the agency did not clcarly explain the theories of liability upon which it based its allegations. For nearly every claim, OTS charged Kaye Scholer with violating the sane four OTS regulations. They are 12 C.F.R. $\$ 563.170$ (c) (formerly 12 C.F.R. § 563.17-1(c) (1986)), requiring record-keeping and disclosure; 12 C.F.R. § 563.180(b)(1) (formerly 12 C.F.R. $\$ 563.18(b)(1)$ (1986)), prohibiting knowingly making false and misleading statements of material facts to the agency and omitting material facts concerning any matters within the agency's jurisdiction; 12 C.F.R. \$513.4(a)(3), prohibiting dilatory, obstructionist, egregious, contemptuous, contumacious, or other unethical or improper professional conduct before the agency; and 12 C.F.R. $\$ 513.4(a)(4)$, prohibiting willfully aiding and abetting the violation of any laws administered by the agency and regulations promulgated thereunder.

Nevertheless, one can draw general distinctions among three types of claims. 
misrepresentations concerned Lincoln's financial position. ${ }^{129}$ Second, OTS accused Kaye Scholer of breaching its professional duties. For instance, OTS claimed that Kaye Scholer failed to provide competent advice when it allegedly advised Lincoln that certain transactions were legally grandfathered under banking regulations while knowing that key documents had been backdated. ${ }^{130}$ Third, OTS charged that on other occasions, Kaye Scholer lawyers made factual representations to the FHLBB that revealed less than all the information known to Kaye Scholer. For example, when Lincoln's accountants resigned, Kaye Scholer transmitted a copy of Lincoln's SEC filing (not prepared by Kaye Scholer) stating that the accountants had given Lincoln a clean bill of health. Kaye Scholer did not tell the FHLBB, however, that, prior to their resignation, Lincoln's auditors gave Kaye Scholer a confidential report raising significant questions about Lincoln's financial condition. ${ }^{131}$ In a similar vein, OTS claimed that Kaye Scholer was aware of information suggesting that certain transactions that Lincoln had classified as loans might be more appropriately classified as joint ventures. Kaye Scholer failed to disclose this information, instead maintaining that the transactions were properly classified as loans. ${ }^{132}$

Assuming that the facts are as OTS alleged them, the first category of claims is relatively uncontroversial from a professional ethics standpoint. Lawyers may not make false statements, ${ }^{133}$ nor may they aid or abet illegal conduct. ${ }^{134}$ The second category of claims is similarly uncontroversial. Although unrelated third parties normally cannot sue a lawyer for malpractice, ${ }^{135}$ OTS receives all the rights the thrift had when it succeeds to the

129. For instance, OTS claimed that Kaye Scholer knew, among other things, that Lincoln engaged in linked transactions involving sham sales of stock or property to related entities at inflated prices in order to create artificial profits, Notice of Charges, supra note 117, paras. 58-73; that Lincoln einployed woefully inadequate underwriting practices, $i d$. paras. 84-87; and that Lincoln employees stuffed and sanitized the files to mask deficiencies in Lincoln's underwriting, id. paras. 76-78. Yet in its 1989 submission to the FHLBB, just four months before the FHLBB shut Lincoln down, Kaye Scholer stated that "Lincoln's managerial skill, its sound diversification of investments and its prudent underwriting are all demonstrated by the unqualified success of its investment program." Id. para. 70. And in its 1987 subinission to the FHLBB, Kaye Scholer maintained that "[w] hat is unusual about Lincoln's underwriting is its particular emphasis on, and the thoroughness of, its underwriting of the collateral." Id. para. 88 .

130. Id. paras. $22-35$.

131. Id. paras. $36-44$.

132. Id. paras. $107-38$.

133. See Model Rules of Professional Conduct Rule 4.1 (1983) ("[A] lawyer shall not knowingly . . . inake a false statement of material fact or law to a third person . . . ."); MODEL CoDE of Professional Responsibility DR 7-102(A)(5) (1980) ("[A] lawyer shall not . . . [k]nowingly make a false statement of law or fact.").

134. See Model Rules of Professional Conduct Rule 1.2(d) (1983) ("A lawyer shall not counsel a client to engage, or assist a client, in conduct that the lawyer knows is criminal or fraudulent ...."); MOdel CODE OF PROFEssional ResponsibIIITY DR 7-102(A)(7) (1980) ("[A] lawyer shall not .. . [c]ounsel or assist his client in conduct that the lawyer knows to be illegal or fraudulent.").

135. See Calamari v. Grace, 469 N.Y.S.2d 942, 945 (App. Div. 1983). 
position of the thrift upon insolvency. ${ }^{136}$ Consequently, OTS may assert the thrift's malpractice claims against its lawyers. Hence, these two categories of claims primarily turn on factual determinations regarding Kaye Scholer's knowledge and conduct.

The third category of claims, by contrast, is controversial. These are the claims that caused the furor in the legal community. These claims are seen as calling into question the appropriate role of the lawyer because even if Kaye Scholer were to concede the facts that OTS alleged, it could still maintain that its representation conformed entirely with professional ethics rules. Thus, these claims have the capacity to alter significantly the lawyer's traditional role. This Comment, therefore, is concerned with the third category of claims.

OTS relied for its third category of clainis on 12 C.F.R. $\S 563.180(\mathrm{~b})(1),{ }^{137}$ which prohibits knowingly making any statement to OTS that omits a material fact concerning a niatter within OTS's jurisdiction. ${ }^{138}$.Although there is scant law interpreting the scope of $\S 563.180(\mathrm{~b})(1)$, Harris Weinstein, former OTS chief counsel, nuaintains that it places a disclosure burden on attorneys similar to the broad disclosure obligations of the Securities and Exchange Commission's controversial rule $10 \mathrm{~b}-5 .{ }^{139}$ That rule penalizes not just false statenients but also the failure "to state a material fact necessary in order to make the statements made, in the light of the circumstances under which they were nrade, not misleading." 140

136. See Steve France, Savings and Loan Lawyers, A.B.A. J., May 1991, at 52, 52; Jackson, supra note 2, at 1026.

137. Formerly 12 C.F.R. $\S 563.18(b)(1)$ (1986).

138. Specifically, the regulation provides:

No savings association or director, officer, agent, employee, affiliated person or other person participating in the conduct of the affairs of such association nor any person filing or seeking approval of any application shall knowingly: (1) Make any written or oral statement to the Office or to an agent, representative or employee of the Office that is false or misleading with respect to any material fact or omits to state a material fact concerning any matter within the jurisdiction of the Office.

OTS has generally argued that Kaye Scholer not only omitted material facts but that the omissions rendered Kaye Scholer's other statements false and misleading. See, e.g., Notice of Charges, supra note 117 , para. 72.

139. Weinstein, supra note 127 , at 395 .

140. 17 C.F.R. $\$ 240.10 \mathrm{~b}-5$ (1993). For a general discussion of when rule $10 \mathrm{~b}-5$ and related provisions penalize the failure to state a material fact, see 4 Lours Loss \& Joer Selioman, Securmes Regulation 2052-57 (3d ed. 1990); 7 id. at 3444-46 (3d ed. 1991). There is much literature on the obligations that the securities laws impose on lawyers. See, e.g., Dennis J. Block \& Charlcs J. Ferris, SEC Rule 2(e) - A New Standard for Ethical Conduct or an Unauthorized Web of Ambiguity?, 11 CAP. U. L. REv. 501 (1982); Joseph C. Daley \& Roberta S. Karmel, Attomeys' Responsibilities: Adversaries at the Bar of the SEC, 24 EMORY L.J. 747 (1975); Stuart C. Goldberg, Policing Responsibilities of the Securities Bar: The Attomey-Client Relationship and the Code of Professional ResponsibilityConsiderations for Expertizing Securities Attorneys, 19 N.Y. L.F. 221 (1973); Roberta S. Karmel, Attorneys' Securities Laws Liabilities, 27 Bus. Law. 1153 (1972); Frederick D. Lipman, The SEC's Reluctant Police Force: A New Role for Lawyers, 49 N.Y.U. L. Rev. 437 (1974); Lewis D. Lowenfcls, Expanding Public Responsibilities of Securities Lawyers: An Analysis of the New Trend in Standard of Care and Priorities of Duties, 74 Colum. L. Rev. 412 (1974); Marc I. Steinberg, Attomey Liability 
OTS has maintained that it usually does not apply $\S 563.180(b)(1)$ to lawyers. But it justified the move in the Kaye Scholer case on the ground that Kaye Scholer allegedly demanded that all FHLBB requests for information be directed to Kaye Scholer. ${ }^{141}$ Because of this "interposition of the firm between the regulators and the institution," 142 OTS alleged that Kaye Scholer was not just Lincoln's lawyer but its agent in the examination process. "This was the basis for the charge that Kaye Scholer made itself responsible as an agent for Lincoln's compliance with the Bank Board's disclosure and recordkeeping regulations."143

Had the case gone to trial, it would have been brought before an administrative law judge in accordance with the procedures for cease and desist orders set out above. ${ }^{144}$ However, Kaye Scholer agreed to settle the case six days after OTS served it with the Notice of Charges. The Settlement Order requires Kaye Scholer to pay OTS $\$ 41$ million in restitution, ${ }^{145}$ and it bars partners Peter Fishbein and Karen Katzman from performing any work for federally insured depository institutions. ${ }^{146}$ In addition, the settlement requires Kaye Scholer to adhere to certain policies in the future. I will discuss only the three most notable.

First, Kaye Scholer must appoint a banking partner with at least ten years banking law experience to supervise Kaye Scholer's representation of insured depository institutions. ${ }^{147}$ For instance, the Settlement Order provides that "[n]o document to be prepared by Kaye Scholer for submission to a federal bank regulatory agency shall he submitted to the agency in the absence of review by the banking partner in charge of the matter and a second partner in the Banking Group."148

Second, the settlement imposes enhanced due diligence obligations on Kaye Scholer. For instance, if Kaye Scholer is retained to provide an opin-

Under the Securities Laws, 45 Sw. L.J. 711 (1991); William K.C. Dippel, Comment, Attorney Responsibility and Carter Under SEC Rule 2(e): The Powers That Be and the Fear of the Flock, $36 \mathrm{Sw}$. L.J. 897 (1982).

141. See Notice of Charges, supra note 117 , paras. $45-47$.

142. Weinstein, supra note 127 , at 397.

143. Id.

144. See supra notes $73-85$ and accompanying text.

145. Peter M. Fishbein, OTS AP No. 92-24, para. 17 (Mar. 1992) [hereinafter Settlement Order].

146. Peter M. Fishbein, OTS AP Nos. 92-25 and 92-26 (Mar. 11, 1992) (Orders of Prohibition from Participating in the Conduct of the Affairs of an Insured Depository Institution).

147. Settlement Order, supra note 145, para. 4. However, OTS provides a de minimis exception to the requirement. The Settlement Order only requires Kaye Scholer to appoint a banking partner as supervisor when Kaye Scholer

(i) acts as general counsel, banking regulatory counsel, or securities counsel to an insured depository institution, or as counsel for such institution in connection with any federal regulatory examination without regard to the anticipated or actual value of such work, or (ii) anticipates performing or performs other legal services for an insured depository institution, excluding workout or collection work, of a value of $\$ 600,000$ or more at Kaye Scholer's regular billing rates during any 12 consecutive month period.

Id.

148. Id. 
ion on a matter and it knows that another law firm previously rendered an opinion on the same matter or a related matter, then Kaye Scholer must obtain the first firm's opinion before issuing its own opinion. If Kaye Scholer's opimion differs from the first firm's, then Kaye Scholer must set forth the other firm's opinion in its own opinion letter and explain why Kaye Scholer reached a different conclusion. ${ }^{149}$

Finally, several settlement provisions were apparently designed to force Kaye Scholer to "practice the whole law," as Harris Weinstein terms it, rather than engaging in "loophole lawyering." 150 For instance, the settlement requires Kaye Scholer to disclose any material facts relating to a banking matter where Kaye Scholer has determined that the facts are not relevant to Kaye Scholer's theory of applicable law but where Kaye Scholer knows that the banking agency may have a different view of the law. ${ }^{151}$ As another example,

Kaye Scholer shall not act as counsel for an insured depository institution client concerning a matter in which a Kaye Scholer attorney knows that one or more of the institution's officers or employees is ... violating any apphicable federal banking statutes or regulations, including by attempting to evade any such statutes or regulations by elevating form over substance. ${ }^{152}$

Although Kaye Scholer settled the case, it vigorously denied OTS's allegations. Kaye Scholer's counsel, Bernard Nussbaum, maintained that the firm was forced to settle because its banks had shut off its line of credit, thereby preventing it from meeting its operating expenses. ${ }^{153}$ Nussbaum has also argued that Kaye Scholer could not expect to win since the administrative proceeding would have been held before OTS. ${ }^{154}$ Kaye Scholer has maintained throughout that it did nothing wrong. ${ }^{155}$ It has repeatedly argued that it was simply fulfilling its professional duty of loyalty to its client. $^{156}$ Kaye Scholer has maintained that if it had disclosed the information that OTS sought, it would have violated its professional ethics obliga-

149. Id. para. 12(f).

150. Harris Weinstein, Issues of Professional Responsibility Arising from the Savings and Loan Failure, Remarks Before the University of Michigan Law School (Mar. 24, 1992), in Emeraino Issues, supra note 91 , at 405,415 .

151. Settlement Order, supra note 145, para. 12(d).

152. Id para. 15(c) (emphasis added).

153. DeBenedictis, supra note 127 , at 60 . Most commentators have accepted Nussbaum's contention. See, e.g., id. at 60; Harvey L. Pitt \& Dixie L. Johnson, The Banking Scandal: An Era of New Standards for Professionals?, N.Y. L.J., Apr. 23, 1992, at 1, 10.

154. See DeBenedictis, supra note 127, at 59; Kaye, Scholer and the New Ethics Imperative, supra note 6, at 65-68; Bernard W. Nussbaum \& Warren R. Stem, FIRREA's Grant of Injunctive and Adjudicative Powers, N.Y. L.J., Sept. 24, 1992, at 1.

155. GILlers \& Simon, supra note 3, at 730 . For Kaye Scholer's claim by claim response to OTS's Notice of Charges, see id. at 772-78.

156. Id. at 778. Kaye Scholer was supported in this contention by ethics expert Geoffrey Hazard. Professor Hazard submitted a swom statement defending Kaye Scholer's conduct on the theory that the firm was acting properly as litigation counsel. Summary of the Expert Opinion of Geoffrey C. Hazard, 
tions. ${ }^{157}$ According to Kaye Scholer, OTS brought suit simply because Kaye Scholer advanced arguments on its client's behalf whicl it believed were supported by the facts and law without going further and disclosing weaknesses in its client's position or contrary arguments available to OTS. ${ }^{158}$ The bottom line, says Kaye Scholer (and others), is that OTS is trying to redefine the role of a lawyer. ${ }^{159}$

\section{III}

\section{The Traditional Role of the Lawyer}

In order to determine whether OTS regulations and procedures do redefine the role of the lawyer, we need to examine the lawyer's traditional role. In the Umited States, our adversarial model of adjudication defines this role. ${ }^{160}$ The adversary system typically pits two contestants-or more precisely, their representatives-against each other to argue their cases before a neutral and largely passive judge. ${ }^{161}$ The parties control the investigation and presentation of evidence and argument. ${ }^{162}$ For the most part, then, the parties designate the proofs and run the process. ${ }^{163}$ Party control is said to preserve individual autonomy and dignity because it gives litigants the "fullest voice possible" in their cases. ${ }^{164}$ Similarly, party control is believed to affirm human individuality by mandating respect for the opinions of each party, rather than the opinions of the "attorney, of the court, or of society at large."165

Jr. (Feb. 25, 1992), reprinted in The Attorney-Client Relationship After Kaye, Scholer, supra note 6 , at $381,394-402$.

157. Edward A. Adams, Repercussions of Kaye Scholer Suit Discussed by Ethics Experts, N.Y. L.J., Mar. 23, 1992, at 1, 2.

158. Gillers \& Simon, supra note 3, at 773.

159. See id. at 778 .

160. "The term [adversary system] has no fixed and precise meaning .... [yet] it is a useful term for identifying a distinctive set of features and style of decisionmaking that is most fully developed in Anglo-American legal systcms ...." Malcolm Feeley, The Adversary System, in 2 ENCYCLOPEDIA OF tHE AMERICAN Judicial System 753, 753 (Robert J. Janosik ed., 1987).

161. Id.

162. Ellen E. Sward, Values, Ideology, and the Evolution of the Adversary System, 64 IND. L.J. 301, 302 (1989); see also Stephan Landsman, The Adversary System: A Description and Defrense 4 (1984) ("T]he parties are responsible for producing all the evidence upon which the decision will be based."); DAvid LuBAN, LAwYers AND Justice: AN EtHICAL Study 57 (1988) (noting that the adversary system assigns the parties responsibility for presenting their own cases and challenging their opponents'); Charles W. Wolfram, Modern Legal Ethics 564 (1986) ("The parties initiate and control the definition of the issues and the presentation of evidence.").

The adversary system of adjudication is frequently contrasted with its continental European counterpart, the inquisitorial system, on precisely this point. See, e.g., LUBAN, supra, at 93-94; Feeley, supra note 160 , at 754 . Judges in inquisitorial systems typically take a more active role in investigating and questioning, while the parties are left with a correspondingly dimimished role. LuBAN, supra, at 94.

163. LANDSMAN, supra note 162 , at 44.

164. Sward, supra note 162 , at 318.

165. LANDSMAN, supra note 162 , at 46 . According to Landsman, party control "provides the litigant a neutral forum in which to air his views and promises that those views will be heard and considered." Id. 
The adversary system requires that the lawyer's role be focused and limited. ${ }^{166}$ The lawyer is expected to be fiercely partisan in order to ensure the sharp adversarial contest that is central to the adversary system. ${ }^{167}$ The lawyer's over-arching professional duty is to represent his client's interests zealously. ${ }^{168}$ The lawyer's goal is not to determine the truth but to win. ${ }^{169}$ The following sections examine two important aspects of the lawyer's role that became relevant in the Kaye Scholer litigation.

\section{A. Partisan Presentation of Evidence}

It is up to the lawyer to present the client's evidence to the tribunal. Lawyers in the adversary system, however, do not merely gather evidence and organize it logically or objectively. ${ }^{170}$ Rather, the lawyer is the client's zealous advocate, and therefore must search for the "best" evidence from the client's point of view and present it in the way most likely to advance the client's ends. ${ }^{171}$ At the same time, the lawyer must challenge the oppo-

166. See LANDSMAN, supra note 162, at $45-46$ ("According to adversary thcory, when each actor performs only a single function, the dispute before the court will be resolved in the fairest and most efficient way.").

The lawyer's specific obligations derive in large part from the legal ethics codes that regulate the profession. Each state has its own ethics rules, but all of the states except California have adoptcd a variant of one of the two model codes promulgated by the American Bar Association. LuBAN, supra note 162, at xxvii. Accordingly, I will rely primarily on the ABA's two model codes. The older code is the Model Code of Professional Responsibility, first adopted in 1969 and revised several timcs since. The more recent code is the Model Rules of Professional Conduct, adopted in 1983.

167. Stephan Landsman, The Decline of the Adversary System: How the Rhetoric of Swift and Certain Justice Has Affected Adjudication in American Courts, 29 BuFf. L. Rev. 487, 495 \& n.32 (1980); see also William H. Simon, The Ideology of Advocacy: Procedural Justice and Professional Ethics, 1978 W1s. L. REv. 29, 36.

168. See Model Code of Professional Responsibility DR 7-101(A), EC 7-1 (1980); see also Model Rules of Professional Conduct Rule $1.3 \mathrm{emt}$. (1983) (encouraging counsel to "act with commitment and dedication to the interests of the client and with zeal in advocacy upon the elient's behalf").

169. Feeley, supra note 160, at 753. That is not to say, however, that the system is not conccrned with truth. Indeed, defenders of the adversary system maintain that the lawyer's sharply defined, partisan role encourages the kind of thorough investigation likely to bring out the truth. See MONROE H. FreedMan, LaWyers' EthICS in AN AdVERSARy System 3 (1975) [hereinafter Freedman, Lawyers' ETHics] ("the adversary system is one of the most efficient and fair methods designed for detcrmining" the truth); LUBAN, supra note 162, at 68-74; Monroe H. Freedman, Professional Responsibility of the Criminal Defense Lawyer: The Three Hardest Questions, 64 Мich. L. Rev. 1469, 1470 (1966) [hereinafter Freedman, The Three Hardest Questions] ("The attorney functions in an adversary system based upon the presupposition that the most effective means of determining truth is to present to a judge and jury a clash betwecn proponents of conflicting views."); Sward, supra note 162, at 316-17. But see Stephen A. Saltzburg, Lawyers, Clients, and the Adversary System, 37 Mercer L. Rzv. 647, 653-54 (1986) (claiming that certain "examples should sufficiently demonstrate to anyone with a sense of reality that the adversary system that Americans have chosen . . . is not based on a search for the truth").

170. Lon L. Fuller, The Adversary System, in Talks on AMERICAN Law 35, 36 (Harold J. Berman ed., rev. ed. 1971).

171. Model Rules of Professional Conduct Rule $3.3 \mathrm{cmt}$. (1983) ("The advocate's task is to present the client's case with persuasive force."). As Professor Fuller put it, the lawyer "is not like a jeweler who slowly turns a diamond in the light so that each of its facets may in turn be fully revealcd. Instead the advocate holds the jewel steadily, as it were, so as to throw into bold relief a single aspect of 
nent's position as vigorously as possible. ${ }^{172}$ The lawyer, then, takes the available facts and molds them into the most plausible, advantageous legal theories possible. ${ }^{173}$ Although lawyers are not permitted to lie, they generally have no affirmative duty to inform an opposing party of relevant facts. ${ }^{174}$

The lawyer's duty to present the client's evidence partisanly is thought to be vitally important to the adversary system. ${ }^{175}$ In the criminal context the lawyer's partisan presentation of evidence is seen as giving voice to the defendant's interests in opposition to the state. ${ }^{176}$ Moreover, it is believed that the factfinder is better able to render an appropriate decision "after listening to the arguments of two vigorous and fiercely partisan advocates."177 If one advocate is not sufficiently zealous, then the factfinder may not have adequate evidence upon which to base her decision. The factfinder might, then, be tempted to engage in an independent investigation which would endanger her neutrality.

\section{B. Duty of Confidentiality}

The duty to represent the client zealously miplies that the lawyer owes the client a duty of loyalty. One important way that lawyers manifest their loyalty is by keeping their clients' confidences. The scope of the lawyer's duty of confidentiality varies slightly under the different ethical codes.

The American Bar Association's (ABA's) most recent ethics code, the Model Rules of Professional Conduct (Model Rules), adopts a strict position. Model Rule 1.6 states that a lawyer cannot reveal information relating to the representation of a client without the client's consent unless it is to defend the lawyer against charges of wrongdoing or to prevent the client from committing a crime that "the lawyer believes is likely to result in imminent death or substantial bodily harm." 178 Moreover, these narrow

it." Fuller, supra note 170, at 35-36; see also Lon L. Fuller \& John D. Randall, Report of the Joint Conference of the ABA and AALS on Professional Responsibility, 44 A.B.A. J. 1159, 1160 (1958) ("The lawyer appearing as an advocate before a tribunal presents, as persuasively as he can, the facts and the law of the case as seen from the standpoint of his client's interest.").

172. Feeley, supra note 160 , at 753 .

173. See Model Code of Professional Responsibiltix EC 7-23 (1980) ("The adversary system contemplates that each lawyer will present and argue the existing law in the light most favorable to his client."). For an interesting discussion of the criminal defense lawyer's duty to present evidence partisanly, see Freedman, The Three Hardest Questions, supra note 169. Professor Freedman argues that the criminal defense lawyer is required by his role in the adversary system to put perjurious clients on the stand and to discredit opposing witnesses known by the lawyer to be telling the truth, even if it means humiliating them. Id. at 1474-78.

174. Model Rules of Professional Conduct Rule $4.1 \mathrm{cmt}$. (1983).

175. "In a very real sense it may be said that the integrity of the adjudicative process itself depends upon the participation of the advocate." Fuller \& Randall, supra note 171, at.1160.

176. See LUBAN, supra note 162 , at 60.

177. Feeley, supra note 160, at 753-54; see also Model Code of Professional Responsibrtity EC 7-19, EC 7-23 (1980); Fuller \& Randall, supra note 171, at 1160-61.

178. Model Rules of Professional Conduct Rule 1.6 (1983). 
exceptions to the duty of confidentiality are merely permissive; lawyers are never required to reveal confidences.

Model Rule 1.6, then, seemingly does not permit a lawyer to disclose information about client fraud. However, the comment to Rule 1.6 does permit a lawyer to withdraw from representation if the client will use the lawyer's services in materially furthering a crime or fraud. ${ }^{179}$ The comment goes on to say that the lawyer may give notice of withdrawal and may withdraw any opimion, affirmation, or document. Some commentators maintain that permitting such "noisy" withdrawals amounts to permitting disclosure, if not of the facts of the fraud, at least of the fact that something is not quite riglit. ${ }^{180}$ That view is likely correct, but then Rule 1.6 may be said to demonstrate the reverence that the duty of confidentiality commands. ${ }^{181}$

Many states have not adopted the Model Rules but have instead retained the ABA's older ethics code, the Model Code of Professional Responsibility (Model Code). The Model Code's general confidentiality rule prohibits lawyers from revealing client confidences; ${ }^{182}$ however, an exception to the confidentiality rule permits disclosure of a client's "intention . . . to commit a crime and the information necessary to prevent the crime."183 But like the Model Rules, the Model Code's exception to confidentiality is discretionary, not mandatory.

The Model Code addresses past client fraud in a different provision. DR 7-102(B)(1) provides:

A lawyer who receives information clearly establishing that ... [h]is client has, in the course of the representation, perpetrated a fraud upon a person or tribunal shall promptly call upon his client to rectify the same, and if his client refuses or is unable to do so, he shall reveal the fraud to the affected person or tribunal, except when the information is protected as a privileged communication. ${ }^{184}$

The ABA Standing Committee on Discipline and Professional Ethics has interpreted the term "privileged communication" broadly to refer not just to information protected by the evidentiary attorney-client privilege but to all

179. See also id. Rule 1.16(b) (permitting withdrawal if "the client persists in a course of action involving the lawyer's services that the lawyer reasonably believes is criminal or fraudulent").

180. See Geoffrey C. Hazard, Jr., Rectification of Client Fraud: Death and Revival of a Professional Norm, 33 EmoRY L.J. 271, 298-303 (1984); Ronald D. Rotunda, The Notice of Withdrawal and the New Model of Professional Conduct: Blowing the Whistle and Waving the Red Flag, 63 OR. L. REv. 455, $478-84$ (1984).

181. See Susan P. Koniak, When Courts Refuse to Frame the Law and Others Frame It to Their Will, 66 S. CAL. L. REv. 1075, 1099-100 (1993) ("[T]he comment's insistence on signs communicates that silence is right and disclosure is wrong.").

182. Model Code of Professional Responsibility DR 4-101(B) (1980).

183. Id. DR 4-101(C)(3).

184. Id. DR 7-102(B)(1) (emphasis added). 
information covered by the lawyer's duty of confidentiality. ${ }^{185}$ In practice, then, this exception swallows the disclosure requirement because information revealing a client's fraud almost always comes within the term "privileged communication." Thus, the clause has been construed to negate the lawyer's duty to rectify client fraud committed in the course of representation. ${ }^{186}$

Although the Model Rules and the Model Code differ in their treatment of confidentiality, ${ }^{187}$ the theory underlying both is the same. Lawyers owe their clients a duty of loyalty, and revealing client confidences is disloyal. Confidentiality is seen as a vital component of both the lawyer-client relationship and the adversary system as a whole. ${ }^{188}$ It is feared that if lawyers were not bound by a duty of confidentiality, then clients would be less likely to seek timely legal assistance and less likely to provide their lawyers with complete information. ${ }^{189}$ Full and frank communication is thought to enable lawyers to assist their clients in conforming with the

185. Under the Model Code, the duty of confidentiality extends to all "information gained in the professional relationship that the client has requested be held inviolate or the disclosure of which would be embarrassing or would be likely to be detrimental to the client." Id. DR 4-101(A).

186. See ABA Comm. on Ethics and Professional Responsibility, Formal Op. 341 (1975); New York State Bar Ass'n, Comm. on Professional Ethics, Op. No. 454 (1976). Moreover, even in the exceedingly rare instances when the information is not gained through a privileged communication, the information must "clearly establish" that the client's conduct is fraudulent before the lawyer is obliged to disclose it.

DR 7-102(B)(1) as originally promulgated did not include the exception for privileged communications; the ABA added the exception in 1974. See Geofrrey C. HAZARD, JR. \& Susan P. Koniak, The Law and Ethics of Lawyering 283-84 (1990). Many states have not adopted the amendment, see id. at 284, but New York did. N.Y. Jud. LAw Code of Professional Responsibility DR 7-102(B)(1) (McKinney 1992).

187. As a practical matter, lawyer conduct under the two codes may vary little. Perhaps, the biggest difference in the codes' treatment of confidentiality is that the Model Code allows lawyers to reveal a client's intention to commit a crime whereas the Model Rules prohibit lawyers from disclosing such an intention unless the crime "is likely to result in imminent death or substantial bodily harm." But since both exceptions are discretionary, a lawyer who does not reveal any information would be behaving ethically under either code.

188. " " $[T]$ he interests served by the strict rule of confidentiality are far broader than merely those of the client, but include the interests of the public generally and of effective judicial administration.' " New York State Bar Ass'n, Comm. on Professional Ethics, Op. No. 562 (1984) (quoting New York State Bar Ass'n, Comin. on Professional Ethics Op. No. 479 (1978)).

189. See id.; FrEEDMAN, LAwYERs' ETHICS, supra note 169, at 5 ("Obviously, ... the client cannot be expected to reveal to the lawyer all information that is potentially relevant ... unless the client can be assured that the lawyer will maintain all such information in the strictest confidence."). 
law. ${ }^{190}$ In addition, confidentiality is believed to preserve the client's autonomy ${ }^{191}$ and constitutional rights. ${ }^{192}$

IV

\section{The Contrast BetweEn the Lawyer's Role in the OTS SYSTEM AND IN THE ADVERSARY SYSTEM}

The description in Part III of the traditional role of the lawyer as defined by the adversary system indicates a tension between the disclosure obligations that OTS sought to impose on Kaye Scholer and the ethical rules that govern the profession. Of course, any comparison between the two sets of obligations in the context of the Kaye Scholer case is problematic for a number of reasons. First, OTS's claims against Kaye Scholer were not litigated. Kaye Scholer never admitted to any wrongdoing and in fact sharply contested many of OTS's factual allegations. ${ }^{193}$ Second, because the claims were not litigated we have no determinative ruling as to the meaning and scope of certain key regulations. ${ }^{194}$ Finally, the professional ethics standards are not always precise and well-defined. Nor is there a uniform system of ethics rules across the country; some states have adopted the Model Rules while others have retained the Model Code, ${ }^{195}$ and

190. Or put another way, if clients communicate freely with lawyers, then lawyers will be able to dissuade clients from engaging in wrongful conduct. But see Harry I. Subin, The Lawyer as Superego: Disclosure of Client Confidences to Prevent Harm, 70 Iowa L. Rev. 1091, 1166 (1985) (criticizing this argument).

19I. There are a number of ways to construct a relationship between lawyer confidentiality and client autonomy. Lawyer confidentiality is most commonly viewed as an instrumental means of enhancing the client's autonomy. Professor Subin describes this argument as the classic defense of confidentiality:

(a) the primary objeetive of the legal system is the preservation of individual autonomy, through the protection of an individual's rights against encroachments by other individuals or the statc; (b) in a complex society individuals can have meaningful access to the legal system ... only if they are represented by attomeys who have the skill to guide them through the process; (c) attorneys can perform this function only if they are privy to all the client's information, because otherwise they would not be able to diagnose properly the legal problem or prescribe a resolution of it; (d) clients will not provide attomeys with all of the facts, including possibly damaging and embarrassing facts, if they belicve that the attomey will disclose those facts; (e) therefore, confidentiality is essential to the preservation of individual autonomy.

Id. at 1160 . See also Sinton, supra note 167 , at 42 (confidentiality reflects fact that the lawyer is an extension of the client's will; the client can use the lawyer as a tool to "invoke his rights and maximize his autonomy").

Part V infra develops a different vision of the relationship between autonomy and the lawyer's role, including the lawyer's duty of confidentiality.

192. "The rule also plays an important role in preserving a client's constitutionally protected (a) right to effective representation by counsel in criminal cases and (b) privilege against selfincrimination." New York State Bar Ass'n, Comm. on Professional Ethics, Op. No. 562 (1984); see also FreEDMAN, LAWYers' ETHICs, supra note 169, at 8.

193. See, e.g., Gillers \& Simon, supra note 3, at 774 (a Kaye Scholer response, denying that it knew that Arthur Andersen lied in a SEC filing).

194. See Jackson, supra note 2, at 1020 ("Further clouding the debate are underlying disagreements as to the substantive law governing sueh financial intermediaries as Lincoln Savings.").

195. And California adopted neither. LuBAN, supra note 162 , at $\mathrm{xxvii}$. 
many have amended the set they chose. ${ }^{196}$ Nonetheless, a general comparison is possible. As mentioned above, this Comment will focus on OTS's claim that Kaye Scholer was obliged to disclose certain material facts to OTS.

The ethics rules prohibit lawyers from making false statements of material facts, but lawyers are otherwise under no general obligation to volunteer facts to an opposing party. ${ }^{197}$ In contrast, OTS relied on 12 C.F.R. $\S 563.180$ (b) to impose just such an obligation on. Kaye Scholer. ${ }^{198}$ An obligation to volunteer material facts is problematic in light of the lawyer's duty of partisan presentation of evidence, the rule of confidentiality, and the ideal of rigidly separate roles that is implicit in adversarial theory.

The adversary system assumes that each party will normally present only the evidence that supports his or her claim. OTS, however, expected Kaye Scholer to volunteer evidence that would weaken Lincoln's claim. For instance, OTS claimed that Kaye Scholer violated OTS regulations because it knew but failed to disclose facts suggesting that certain transactions should be classified as joint ventures rather than loans. ${ }^{199}$ Kaye Scholer maintained that it properly relied on Lincoln's accountants who had classified the transactions as loans; therefore, it believed that it had a firm basis for advocating that classification. ${ }^{200}$ Similarly, the Settlement Order highlights the conflict between OTS's expectations and the lawyer's duty to present evidence partisanly. The Settlement Order requires Kaye Scholer to disclose any material facts relating to a banking matter where Kaye Scholer has determined that the facts are not relevant to Kaye Scholer's theory of applicable law and regulations but where Kaye Scholer knows that the banking agency may have a different view of the law and regulations. ${ }^{201}$

196. See HAZARD \& KonIAK, supra note 186, at 292 (chart of state variations to Model Rule 1.6).

197. Model Rules of Professional Conduct Rule 4.1 \& cmt (1983).

198. As noted above, see supra text accompanying notes 141-143, OTS justified charging Kaye Scholer with violating 12 C.F.R. $\$ 563.180(b)(1)$ on the ground that by interposing itself between Lincoln and OTS, Kaye Scholer acted as Lincoln's agent rather than merely as Lincoln's lawyer. OTS's distinction between lawyer and agent is problematic for à number of reasons. First, OTS has established no guidelines for determining at what moment a lawyer steps into the role of agent. Second, the basis for the distinction itself is arguably contrary to adversarial procedure. As a general proposition, once a party has retained counsel, the opponent's counsel is required to deal solely with that party's lawyer. See Model Code of Professional Responsibility DR 7-102 (1980). Third, the distinction is likely irrelevant; if it chooses, OTS can impose the same obligations on law firms who do not "interpose" themselves between the regulators and the institution. As noted above, see supra text accompanying notes $48-50$, OTS has enforcement powers over institution-affiliated parties-a class that includes lawyers. Finally, it may be impossible for a lawyer to fulfill his duty of zealous representation without falling into the role of "agent," as OTS defines it.

199. Notice of Charges, supra note 117, paras. 107-22. .

200. See Gillers \& Simon, supra note 3 , at 773, 776-77.

201. Settlement Order, supra note 145, para. 12(e). Of course the Settlement Order is not law. It also may not be the agency's articulation of how all firms should conduct their practices. For one thing, the language of the Settlement Order is substantially similar to the language in the OTS Temporary Cease and Desist Order. Nonetheless, the Order does represent OTS's view of how Kaye Scholer 
According to the professional ethics rules, Kaye Scholer had an obligation to present the evidence in the light most favorable to Lincoln. Thus, in the loan/joint venture example, Kaye Scholer's conduct would seem to be acceptable, and perhaps even obligatory. OTS's theory seems to be that, instead of being obligated to present the evidence partisanly, lawyers are to share the facts with the agency so that the agency can come to the "proper" decision. While there is nothing illogical about establishing an adjudicatory system in which the parties are under an obligation to volunteer all the evidence to their opponents and to the tribunal, ${ }^{202}$ that is not the adversary system.

OTS's claims are also in tension with the lawyer's duty of confidentiality. Using the same example, both the Model Rules and the Model Code would likely prohibit a lawyer from disclosing the facts OTS sought. The Model Rules prohibit lawyers from disclosing client confidences unless the lawyer reasonably believes that disclosure is necessary to prevent the client from committing a crime likely to result in imminent death or substantial bodily harm. No violent crime was threatened here, so the Model Rules would require Kaye Scholer to keep mum. Similarly, none of the Model Code's exceptions to confidentiality would fit the facts of this case. ${ }^{203}$ Furthermore, the permissive exceptions to the duty of confidentiality would not even be implicated unless Kaye Scholer reasonably believed that Lincoln was acting illegally; Kaye Scholer, however, claimed that a creditable argument could be made in favor of Lincoln's position. Thus, according to the current ethics rules, Kaye Scholer almost certainly had no obligation to volunteer the information and likely had an obligation not to disclose it.

Finally, a duty to volunteer adverse information violates principles of rigid role separation. Adversarial theory suggests that the advocate's role must be sharply defined and have a single purpose in order to be effective. A lawyer cannot be a zealous advocate, eagerly serving the client's interests, if every time he says anything to OTS he has to hand over all relevant adverse facts so that OTS can make an informed, "accurate" decision.

In summary, the duty to volunteer adverse information is in tension with the most fundamental aspect of the adversary system: the adversarial nature of the litigation. The OTS system replaces the battle model of adju-

should conduct its practice, and other firms in similar positions would be foolish not to consider it when deciding how to represent clients before OTS.

202. An inquisitorial model of adjudication might be considered such a system. In Gcrmany, for example, the civil procedure code requires parties to make "complete" (vollständig) statemcnts regarding the factual cireumstances underlying the case. ZiviLPRozEssordnuno § 138(1) (F.R.G.). This is understood to require that adverse facts be volunteered. See, e.g., 1 MONCHENER KOMMENTAR zUR ZiviprozessordNuNo 992 (Gerhard Lüke \& Alfred Walchshöfer eds., 1992) (collecting authorities).

203. If, in this example, Lincoln were threatening criminal conduct, then the Model Code would permit but not require Kaye Scholer to disclose the information. See supra note 183 and accompanying text. 
dication with a cooperative model; the lawyer is to work with the agency to advance a common goal.

This Part has concluded that OTS sought to impose obligations on Kaye Scholer that are in tension with the lawyer's traditional obligations. And most commentators have framed the Kaye Scholer controversy in just these terms; they have examined OTS's actions and Kaye Scholer's responses in light of the traditional role of the lawyer. ${ }^{204}$ The Kaye Scholer case does implicate the lawyer's professional role, as this Part amply demonstrates; however, it is the thesis of this Comment that the conflict surroundimg that professional role points to a more fundamental conflict: a conflict about what it means to be a citizen. The following Part considers the concept of the citizen embodied in our democratic form of government and relates that concept to the adversary system of adjudication. Part VI then examines an alternative model of the regulated person that underlies the OTS system.

\section{$\mathrm{V}$ \\ The Adversary System's Conception of The Citizen}

The tension, described above, between the role of the lawyer as defined by the adversary system and that conceived by OTS reflects more fundamentally the two systems' different visions of the citizen and the citizen's relationship with the state. Our traditional concept of the citizen grows out of our democratic form of government. One way of understanding the central values that underlie a democratic government is by contrasting democracy with autocracy. ${ }^{205}$ Under this view, the difference between democracy and autocracy rests on the distinction between autonomy and heteronomy:

democratic forms of government are those in which the laws are made by the same people to whom they apply (and for that reason they are autonomous norms), while in autocratic forms of government the law-makers are different from those to whom the laws are addressed (and are therefore heteronomous norms). ${ }^{206}$

204. See, e.g., Gillers \& Simon, supra note 3, at 729-31; Brickman, supra note 6; Dennis E. Curtis, Old Knights and New Champions: Kaye Scholer, the Office of Thrift Supervision, and the Pursuit of the Dollar, 66 S. CAL. L. Rev. 985, 985-1002 (1993); Jackson, supra note 2, at 1025-32; Peter C. Kostant, When Zeal Boils Over: Disclosure Obligations and the Duty of Candor of Legal Counsel in Regulatory Proceedings after the Kaye Scholer Settlement, 25 ARIz. ST. L.J. 487 (1993); Podgers, supra note 6.

205. See Hans Kelsen, General Theory of Law and State 283-84 (Anders Wedberg trans., 1946) (criticizing as "superficial" the traditional classification which distinguishes between monarchy, aristocracy, and democracy based on the number of people in whom power rests and proposing as inore "correct" a distinction between autocracy and democracy "based on the idea of political freedom").

206. Norberto Bobbio, Democracy and Dictatorship: The Nature and Limits of State Power 137 (Peter Kennealy trans., 1989); see also CARL Cohen, Democracy 268-70 (1971) (describing democracy as an autonomous, rather than heteronomous, form of government); H.B. MAYO, 
This distinction between autonomy and heteronomy highlights self-determination as a fundamental value embodied in democracy. ${ }^{207}$ In democracies, citizens are self-determining because they live under the laws of their own choosing. ${ }^{208}$ "[L]aws and rules inposed by an outsider would violate the self-determination of all those subject to the laws." 209

Basic to this understanding of democracy, with its emphasis on the value of self-determination, is the notion that the citizens who comprise a democracy are autonomous. ${ }^{210}$ We cannot speak of citizens living under law of their own choosing unless we assume that these citizens are free to make such choices. ${ }^{211}$ For this reason, Professor Post concludes that " $[t]$ he ascription of autonomy is ... the transcendental precondition for the possibility of democratic self-determination."212 As he puts it, "democracy conceives its citizens ... as free and independent persons capable and determined to decide their own destiny."213 Not surprisingly, then, this conception of the autonomous citizen underlies several provisions of the United States Constitution. ${ }^{214}$ Indeed, Professor Richards observes that

An Introduction to Democratic Theory 94 (1960) (in democracies the "[a]uthority to make decisions binding on the citizens is located in the body of citizens and not elsewhere").

207. KELSEN, supra note 205, at 284-86.

208. Robert A. Dahl, Democracy and Trs Crmics 89 (1989). Dahl notes:

The most celebrated exposition of this argument is to be found in the Social Contract; indeed in that work Rousseau explicitly set out to "find a form of association that defends and protects the person and goods of each associate with all the common force, and by means of which each one, uniting with all, nevertheless obeys only himself and remains as free as before."

Id. (quoting Jean-Jacques Rousseau, ON the Social Contract, with the Geneva Manuscript and Polmical ECONOMY 53 (Roger D. Masters \& Judith R. Masters eds., 1978) (1762)).

It has been argued, however, that democratic governments cannot be justified on the basis of selfdetermination because the losing minority in any given contest does not live under the laws of its own choosing. For different approaches and responses to this difficulty, see $i d$. at 89-90; CAROL C. GourD, Rethinking Democracy: Freedom and Social Cooperation in Polmics, Economy, and Society 228-46 (1988); Ketrh Graham, The Battle of Democracy: Conflict, Consensus and the Individual 75-93 (1986); Willtam N. Nelson, ON Justifying Democracy $62-65$ (1980); Robert C. Post, Between Democracy and Community: The Legal Constitution of Social Form, in Democratic CoмmunTrY, NOMOS XXXV 163, 169-72 (John W. Chapnan \& Ian Shapiro eds., 1993).

209. DAHh, supra note 208 , at 108.

210. Id. at 105 ("That personal autonomy and thus inclusion as a full citizen in a democratic order are necessary to self-determination is even more obvious."); GrAHAM, supra note 208, at 33; Post, supra note 208, at 174 ("[D]emocracy posits persons with autonomous selves."); see also CoHEN, supra note 206 , at 270 ("[T]he autonomous character of democratic government is its most fundamental and perhaps most important feature.").

211. DAHL, supra note 208, at 105 . "The word 'autonomy' is obviously derived from the Greek stems for 'self and 'law' or 'rule,' and means literally 'the having or making of one's own laws.' " Joel Feinberg, Autonomy, in THE INNer CrTADEL 27, 27 (John Christman ed., 1989).

212. Robert Post, Managing Deliberation: The Quandary of Democratic Dialogue, 103 Eтrics 654, 672 (1993); see also David A.J. Richards, Autonomy in Law, in THE INNER CrTADEL supra note 211, at 246, 246 ("Autonomy is, I believe, a constitutive normative ingredient of American democratic constitutionalism because it specifies the empirical and normative conditions for the value of selfgovernment essential to the very legitimacy of this form of government.").

213. Post, supra note 212, at 665 n.44.

214. See infra notes 228-39; see also Joel Feinberg, Autonomy, Sovereignty, and Privacy: Moral Ideals in the Constitution?, 58 Notre DaME L. Rev. 445, 446 (1983) (observing that the Supreme Court 
"[a]utonomy ... plays the role that it does in American constitutional law because it specifies the normative value of self-government that is the ultimate aim that the constitutional design ... serves."215

The close relationship between democracy and citizen autonomy has been widely discussed. What has not been adequately attended to, however, is that this democratic conception of the autonomous citizen is also embodied in our adversary system of adjudication. This model of the citizen is most apparent in criminal adjudication, where the citizen's relationship with the state is most clearly at issue, so I will begin my discussion with the adversary system in the criminal context. I will then examine civil litigation and suggest that although it is oriented toward the goal of efficient administration of justice and is willing to manipulate the citizen's role to achieve that end, the role of the citizen reflected in civil litigation mirrors in its general contours that of the autonomous citizen in criminal litigation. ${ }^{216}$

Criminal adjudication is structured so as to prevent the government from using citizens solely as tools for furthering the government's goals. Although the government's goal of punishing those who fail to conform their behavior to the substantive criminal law is undoubtedly legitimate and desirable, criminal adjudication is nonetheless characterized by constitutional guarantees and structural features that are designed to frustrate the efficient attainment of that goal. ${ }^{217}$ These impediments can be seen as aimed at limiting the state's power over citizens; by doing so, they reflect the citizen's autonomous and distinct role vis-à-vis the state. ${ }^{218}$

One such impediment is the Fifth Amendment's privilege against selfincrimination. The privilege has been interpreted broadly to apply in a variety of settings. ${ }^{219}$ For instance, a defendant has the "unfettered right to sit

has found the concept of personal autonomy or self-determination "lurking in various shadowy crevices of the Bill of Rights"); Richards, supra note 212, at 246 ("[A]utonomy in American constitutional law connects to a larger moral and political conception of self-governing agents . . .."). See generally Rogers M. Smith, The Constitution and Autonomy, 60 TEx. L. Rev. 175 (1982).

215. Richards, supra note 212 , at 251.

216. Although OTS suits are nominally civil, the appropriateness of that characterization is open to question. See infra text accompanying notes 343-48.

217. The Anglo-American adversary system has

erected a variety of barriers to prosecution and surrounded the criminally accused with a host of legal protections [including] the standard of proof in criminal cases, the presumption of innocence, the right to confront adverse witnesses, the right to have compulsory process for obtaining witnesses, the right to silence, exclusionary rules, and the right to counsel.

Feeley, supra note 160 , at 756.

218. See Rogers M. Smith, Liberalism and American Constitutional Law 14 (1985) ("[G]overnment should be limited so as to free individuals to undertake private as well as public pursuits of happiness, even if this option erodes public spiritedness in practice.").

219. "[T]here is no 'the' privilege. It is many things in as many settings." 8 JoHN H. WIGMORE, Evidence $§ 2251$, at 296 (John T. McNaughton ed., rev. ed. 1961); see also Miranda v. Arizona, 384 U.S. 436, 461 (1966) ("In this Court, the privilege has consistently been accorded a liberal construction."). 
silent throughout the course of a criminal trial."220 The prosecution is not permitted even to call the defendant to the stand. ${ }^{221}$ A person accused of a crime may also remain silent while in custody prior to trial. ${ }^{222}$ Moreover, witnesses may refuse to disclose self-incriminating information in civil cases, ${ }^{223}$ and before grand juries, ${ }^{224}$ legislative committees, ${ }^{225}$ and administrative tribunals. ${ }^{226}$ Finally, the privilege protects not only evidence that in itself would support a conviction but evidence that would furnish a link in the chain of evidence needed to prosecute. ${ }^{227}$

By shielding the citizen from nonconsensual interrogation, this wideranging privilege frustrates the government's legitimate interest in acquiring information about criminal activities. In this way, the privilege reflects our democratic ascription of citizen autonomy. The privilege acknowledges that citizens exist in a private realm and have private interests and objectives. $^{228}$ Indeed, the Supreine Court has justified the privilege in just these terms, proclaiming in Miranda $v$. Arizona:

[W] may view the historical development of the privilege as one which groped for the proper scope of governmental power over the citizen. As a "noble principle often transcends its origins," the privilege has come rightfully to be recognized in part as an individual's substantive right, a "right to a private enclave where he may lead a private life. That right is the hallmark of our democracy."229

Similarly, in United States $v$. Wade, ${ }^{230}$ the Court stated that " $[\mathrm{t}]$ he privilege historically goes to the roots of democratic and religious principle. ... The roots of the privilege ... go to the nature of a free man and to his relationship to the state."231

220. Charles E. Moylan, Jr. \& John Sonsteng, The Privilege Against Compelled Self-Incrimination, 16 WM. Mrtchell L. Rev. 249, 264 (1990).

221. See Griffin v. California, 380 U.S. 609, 614 (1965) (characterizing the defendant's refusal to take the stand as a "constitutional privilege" and holding that a prosecutor may not invite the jury to draw any adverse inference from it).

222. Miranda v. Arizona, 384 U.S. 436, 461 (1966).

223. McCarthy v. Amdstein, 266 U.S. 34, 40 (1924).

224. Counselman v. Hitchcock, 142 U.S. 547, 564 (1892).

225. Watkins v. United States, 354 U.S. 178, 195-96 (1957).

226. In re Groban, 352 U.S. 330, 333 (1957); id. at 336-37 (Frankfurter, J., concurring); id. at 345 46 (Black, J., dissenting).

227. Hoffman v. United States, 341 U.S. 479, 486-87 (1951).

228. See Smith, supra note 214, at 191; see also Charles Fricd, Privacy, 77 YALE L.J. 475, 488 (1968) (the privilege against self-incrimination is an "example of a contingent, symbolic recognition of an area of privacy as an expression of respect for personal integrity"); Robert S. Gerstein, Privacy and Self-Incrimination, 80 ErHIcs 87, 93 (1970) (compelling self-incriminating statcments is inconsistent with the belief that citizens are frce agents).

229. 384 U.S. 436, 460 (1966) (quoting United States v. Grunewald, 233 F.2d 556, 579, 581-82 (2d Cir. 1956) (Frank, J., dissenting), rev'd, 353 U.S. 391 (1957)).

230. 388 U.S. 218 (1967).

231. Id. at 261 (Fortas, J., concurring in part and dissenting in part). "Expressions are legion in opinions of this Court that the protection of personal privaey is a central purpose of the privilege against compelled self-incrimination. ... . The privilege reflects 'our respect for the inviolability of the human 
The Fourth Amendment can be viewed as expressing a similar conception of the citizen. ${ }^{232}$ Generally speaking, the Fourth Amendment is interpreted as requiring the government to secure a warrant supported by probable cause before conducting a search. ${ }^{233}$ In limited circumstances, the Court has approved searches without warrants; ${ }^{234}$ however, even warrantless searches inust normally be supported by probable cause. ${ }^{235}$ The probable cause requirement is intended "to safeguard citizens froin rash and unreasonable interferences with privacy and from unfounded charges of crime."236 Like the privilege against self-incrimination, then, the warrant and probable cause requirements reflect the citizen's right to a private realm. ${ }^{237}$ Even though the state has a legitimate interest in obtaining evidence of crime, the state ordinarily cannot simply intrude into a citizen's realn1; it nuust have special justification to do so, in the form of a warrant or probable cause.

Finally, and perhaps most inportantly, the very fact that criminal litigation is fiercely adversarial reflects the system's respect for the citizen's autonomy vis-á-vis the state. The adversary systen 1 envisions a pitched battle between equals to be decided by an independent, neutral and passive decisionmaker. ${ }^{238}$ The state does not hold a privileged position in litiga-

personality . . . '" Fisher v. United States, 425 U.S. 391, 416 (1976) (Brennan, J., concurring in the judgment) (quoting Murphy v. Waterfront Comm'n, 378 U.S. 52, 55 (1964)); see also Tehan v. United States ex rel. Shott, 382 U.S. 406, 416 (1966) (stating that privilege reflects "the concern of our society for the right of each individual to be let alone"); Andresen v. Maryland, 427 U.S. 463, 477 (1976) (describing the privilege against self-incrimination as protecting privacy).

232. See Tehan, 382 U.S. at 416 (observing that the Fourth Amendment is like the Fifth Amendment in that it reflects society's concern with the right of the individual to be left alone); see also Robert B. McKay, Self-Incrimination and the New Privacy, 1967 SuP. CT. REv. 193, 211 (noting that the Fourth Amendment prohibitions against unreasonable search and seizure and the privilege against self-incrimination "reinforee each other in the interest of privacy protection").

233. Payton v. New York, 445 U.S. 573, 586 (1980); United States v. United States District Court, 407 U.S. 297, 315-16 (1972).

234. See O'Connor v. Ortega, 480 U.S. 709, 719-22 (1987) (search of government employee's office by supervisor); New Jersey v. T.L.O., 469 U.S. 325, 340 (1985) (search of student's purse by public school officials).

235. Skinner v. Railway Labor Executives' Ass'n, 489 U.S. 602, 624 (1989).

236. Brinegar v. United States, 338 U.S. 160, 176 (1949).

237. See Warden v. Hayden, 387 U.S. 294, 304 (1967) ("[T] he principal object of the Fourth Amendment is the protection of privacy .....); id. at 313 (Douglas, J., dissenting) (Fourth Amendment "creates a zonc of privacy that may not be invaded by the police").

238. Stephan Landsman, A Brief Survey of the Development of the Adversary System, 44 Orio ST. L.J. 713, 714 (1983). The Constitution of Massachusetts provides that "[i]t is the right of every citizen to be tried by judges as free, impartial and independent as the lot of humanity will admit." Mass. ConsT. pt. I, art. XXIX, quoted in Fuller, supra note 170, at 35.

The Due Process Clause guarantees impartial treatment in adjudicatory proceedings. See Judith K. Meierhenry, The Due Process Right to an Unbiased Adjudicator in Administrative Proceedings, 36 S.D. L. REv. 55I (1991). To this end, adversarial theory insists on keeping separate the functions of the advocate and the decisionmaker. Fuller, supra note 170 , at 34 . The decisionmaker inust withhold judgment "until all the evidence has been examined and all the arguments have becn heard." Id. at 35. "Adversary theory suggests that if the decision maker strays from the passive role, he runs a serious risk of prematurely committing hinself to one or another version of the facts and of failing to appreciate the 
tion; the state's objectives, legitimate and desirable though they may be, do not automatically define the nature, or control the result, of the inquiry. Rather, the adversary system places the state in the role of a private actor. Both the state and the citizen have the opportunity to present their best evidence before the tribunal.

These structural features and constitutional guarantees suggest that although the state may seek to advance legitimate objectives, the state can only go so far and can only use certain means. The adversary system in the criminal context establishes citizens as autonomous and separate from the state. They cannot be used solely as tools to advance the state's goals; rather, their private interests and objectives must be acknowledged and considered. In this way the adversary system reflects the democratic premise "of independent citizens who desire to fashion their social order in a manner that reflects their values and commitments."239

Thinking about the adversary system in this way helps us better to understand the role of the lawyer that the system gives rise to. The adversary system is structured so as to constitute autonomous citizens, and the traditional role of the lawyer, as described in Part III, is an essential element of that structure. The adversary system contemplates autonomous litigants who marshal their evidence and present their facts in the way most likely to advance their independent interests and objectives. In keeping with that assumption, the adversary system constructs advocates who are bound to be loyal: advocates who give voice to the citizen's interests against the state. Thus, it is only fitting that while the lawyer cannot lie, he is under no obligation to volunteer adverse information to his client's opponent. ${ }^{240}$ In this way we can see the lawyer's role, like the system that defines it, as founded on the presumption of citizen autonomy.

Note that my position should not be mistaken for related arguments that defend the lawyer's traditional role in the adversary system on the ground that it maximizes the client's autonomy. Professor Stephen Pepper provides an example of such an argument. ${ }^{241}$ Professor Pepper argues that in our highly legalized society, autonomy is often dependent on access to the law. ${ }^{242}$ In such a society, access to law requires the assistance of a

value of all the evidence." LANDSMAN, supra note 162, at 2-3. Indeed, the history of the adversary system is in large part the evolution in the role of the decisionmaker from interested party to disinterested, passive observer. Feeley, supra note 160 , at 755 . Early jurors were selectcd from the locality in which the dispute arose and were often familiar with the events leading to the dispute. Landsman, supra, at 722 . Early judges were "agent[s] of the crown who actively made inquiries and conducted proceedings in order to protect and promote the interests of the crown." Feeley, stpra note 160 , at 755 . By the eighteenth century, however, juries were for the most part neutral and passive, and judicial neutrality was achieved in the nineteenth century. Landsman, supra, at 731-32.

239. Post, supra note 208, at 173.

240. Model Rules of Professional Conduct Rule $4.1 \mathrm{cmt}$. (1983).

241. Stephen L. Pepper, The Lawyer's Amoral Ethical Role: A Defense, A Problem, and Some Possibilities, 1986 AM. B. Found. Res. J. 613.

242. Id. at 617 . 
lawyer. ${ }^{243}$ Thus, by providing access to the law, the lawyer is the means through which the client can attain autonomy. ${ }^{244}$ By contrast, I am concerned with the antecedent question: what is the image of the citizen upon which our legal system is based? Approaching the issue in this way leads me to conclude that the adversary systein presupposes autonomous citizens. The lawyer's role is defined in the way that it is, not in order that we might secure the litigant's autonomy, as Professor Pepper asserts, but because from the outset we assume the litigant's autonomy.

Turning now to civil litigation, the model of the citizen looks somewhat different. While criminal adjudication functions to define the citizen's relationship with the state, civil litigation is oriented towards the goal of administering justice between private parties. ${ }^{245}$ Much of the structure and procedures of civil litigation attests to the system's willingness to manipulate litigants instrumentally in furtherance of that goal. ${ }^{246}$ For instance, the stated purpose of the Federal Rules of Civil Procedure is to "secure the just, speedy, and inexpensive determination of every action."247 Accordingly, the neutral, umpireal judge of criminal litigation is often replaced in civil litigation by the inanagerial judge who is intent on resolving disputes efficiently. ${ }^{248}$ And in keeping with the goal of efficient adjudication, certain

\section{Id.}

244. Id.

245. Cf. Mary M. Cheh, Constitutional Limits on Using Civil Remedies to Achieve Criminal Law Objectives: Understanding and Transcending the Criminal-Civil Law Distinction, 42 HASTnas L.J. 1325, 1325 (1991) ("The Constitution, statutes, and the common law all draw fundamental distinctions between criminal proceedings, which emphasize adjudication of guilt or innocence with strict adversarial protections for the accused, and civil proceedings, which emphasize the rights and responsibilities of private parties.").

246. Robert C. Post, The Management of Speech: Discretion and Rights, 1984 Sur. Cr. Rev. 169, 202 ("[T]he judicial system, like any other government institution, needs to accomplish its goals ....").

247. FED. R. Crv. P. 1.

248. Much has been written about the trend in civil litigation from passive judges to "managerial" judges; that is, to judges who are actively involved in pretrial processing of civil cases. See, e.g., Landsman, supra note 162, at 30-32; Abram Chayes, The Role of the Judge in Public Law Litigation, 89 HARv. L. Rev. 1281, 1298 (1976); E. Donald Elliott, Managerial Judging and the Evolution of Procedure, 53 U. CHI. L. Rev. 306 (1986); Mare Galanter, The Emergence of the Judge as a Mediator in Civil Cases, 69 Judicature 257 (1986); Herbert M. Kritzer, The Judge's Role in Pretrial Case Processing: Assessing the Need for Change, 66 Judicature 28 (1982); Robert F. Peckham, The Federal Judge as a Case Manager: The New Role in Guiding a Case from Filing to Disposition, 69 CALIF. L. Rev. 770, 770-73 (1981); Judith Resnik, Managerial Judges, 96 Harv. L. Rev. 374 (1982); Stephen A. Saltzburg, The Unnecessarily Expanding Role of the American Trial Judge, 64 VA. L. REv. 1 (1978); see also Amendments to the Federal Rules of Civil Procedure, 97 F.R.D. 165, 213 (U.S. 1983) (advisory committee notes to rule 16) ("encourag[ing] forceful judicial management" of the entire pretrial phase). Professor Resnik describes the emergence of managerial judges as a reaction to the real or perceived inefficiencies in the court system. Resnik, supra, at 395-402. For instance, managerial judges typically seek to encourage and facilitate settlements. See Galanter, supra.

It has becn said that the Federal Rules of Civil Procedure "vindicated a particular version of judicial administration that sharply modified the preexisting adversary control over all aspects of litigation" and "established on a secure footing the power of the judge as the manager of the case." Donald $L$. Horowitz, Decreeing Organizational Change: Judicial Supervision of Public Institutions, 1983 DuKE L.J. $1265,1271$. 
constitutional protections that impede the government's ability to pursue its goals, like the self-incrimination clause, for example, do not apply in civil litigation. $^{249}$ Indeed, liberal discovery rules may require litigants to disclose to their opponents enormous amounts of information, ${ }^{250}$ much of which is undoubtedly harmful to their interests. ${ }^{251}$ Moreover, the newly amended Rule 26 of the Federal Rules of Civil Procedure increases the instrumental control over litigants in the name of efficiency. ${ }^{252}$ Rule 26(a)(1) now requires litigants automatically to disclose "certain basic information" without the antecedent discovery requests required by the former version of that rule. ${ }^{253}$

Certain duties of the lawyer in civil litigation also reflect the system's increased concern with the efficient administration of justice. For instance, Model Rule 3.3 prohibits lawyers in civil proceedings from bringing or defending a proceeding, or asserting or controverting an issue therein, unless there is a nonfrivolous basis for doing so, although it permits criminal defense lawyers to assert frivolous defenses in order "to require that every element of the case be established."254 Moreover, the rules prohibiting a lawyer from presenting false evidence to a tribunal vary depending on whether the proceedings are criminal or civil. ${ }^{255}$ Civil litigation's increased

249. See Ullman v. United States, 350 U.S. 422,430 (1956) (testimony may be compelled even if it leads to "loss of job" and "general public opprobrium," as long as there is immunity from criminal prosecution); United States ex rel. Bilokumsky v. Tod, 263 U.S. 149, 155 (1923) (adverse inference may be drawn from silence in a civil proceeding); see also Baxter v. Palmigiano, 425 U.S. 308, 318-19 (1976) (extending Tod to prison disciplinary proceedings).

250. The scope of the information that may be discovered is very broad. Rule 26(b)(1) of the Federal Rules of Civil Procedure permits discovery of any information reasonably calculated to lead to the discovery of admissible evidence and not protected by privilege.

251. Liberal discovery rules have been said to promote litigation efficiency. See Jeffrey J. Mayer, Prescribing Cooperation: The Mandatory Pretrial Disclosure Requirement of Proposed Rules 26 and 37 of the Federal Rules of Civil Procedure, 12 REv. LrTIG. 77, 87 (1992); see also Post, supra note 246, at 194-96 (maintaining that pretrial discovery is a regine of judicial administration, rather than adjudication).

252. See Mayer, supra note 251, at 94 ("[D]isclosure would seem to mitigate the varied concerns that cause diseovery misuse and overuse.").

253. Amendments to the Federal Rules of Civil Procedure, 113 S. Ct. $475,701.02$ (interim ed. 1993) (advisory committee notes on Rule 26). This "basic information" includes all documents held by a party "that are relevant to disputed facts alleged with partieularity in the pleadings." FED. R. CIV. P. $26(a)(1)(B)$. Interestingly, the real or perceived "discovery crisis" which spawned the new Rule 26 has also brought calls to eliminate discovery entirely. See Loren Kieve, Discovery Reform, A.B.A. J., Dec. 1991, at 79, 81; Richard E. Moot, Consider Doing No Discovery, LmG., Fall 1988, at 36.

254. Model Rules of Professional Conduct Rule 3.1 (1983).

255. Id. Rule $3.3 \mathrm{cmt}$. The comment states that "[e]xcept in the defense of a criminal accused, the rule generally recognized is that, if necessary to rectify the situation, an advocate must disclose the existence of the client's deception to the court or to the other party" (emphasis added). The comment goes on to note that "[w] hether an advocnte for a criminally accused has the same duty of disclosure [as an advocate for a litigant in a civil suit] has been intensely debated," and then presents three possible "resolutions" of the problem. 
concern with accurate, efficient adjudication is believed to justify placing greater disclosure obligations on lawyers practicing in that realin. ${ }^{256}$

On the other hand, although the above-mentioned features of civil litigation instruinentally inanipulate the litigant's role in furtherance of the system's goal of efficient dispute resolution, the role of the citizen reflected in civil litigation mirrors, at least in its fundamental contours, the inodel of citizen autonomy constituted by criminal litigation. Liberal discovery rules notwithstanding, civil litigation is still highly adversarial. ${ }^{257}$ Indeed, the new Rule 26 has been almost universally condemned because it is seen as diluting the adversarial nature of the proceedings and endangering the ideal of zealous representation. ${ }^{258}$ Accordingly, numerous federal districts have

256. Id. (although a disclosure of the client's deception to the court "can result in grave consequences ... the alternative is that the lawyer cooperate in deceiving the court, thereby subverting the truth-finding process which the adversary system is designed to implement").

257. Indeed, the term "adversary system" is used to describe both civil and criminal adjudications in the United States. See LuBAN, supra note 162, at xx ("The adversary system of justice . . . lies at the core of Anglo-American legal procedure . . . ."); Sward, supra note 162, at 301 ("The hallmark of American adjudication is the adversary systein").

The adversarial nature of civil litigation can be highlighted by contrasting our adversary systein with the inquisitorial system, the adjudicatory system prevalent in continental European countries such as France, Germany, and Italy. The inquisitorial system can be seen as managed for a specific goal: determining truth. See LANDSMAN, supra note 162, at 49 ("[T]he inquisitorial process is firmly committed to the search for material tnuth."). Thus, the resources and the functions of the participants are ordered to achieve this goal. For instance, judges in inquisitorial systems take a very active role in seeking the truth. In a German criminal trial, the presiding judge "decides the sequenee of proof-taking and conducts the bulk of the questioning of witnesses. ... [She] decides whether witnesses other than those nominated by the parties should be called; in her hands also lies the decision whether to call expert witnesses, and if so, the choice of experts." LuBAN, supra note 162, at 94 .

The lawyer's role in inquisitorial systems is correspondingly dimimished, and the professional ethics rules in such systems serve further to neutralize partisanship and orient lawyers toward truthseeking. Legal ethics in inquisitorial systems principally define the lawyer's status as an "independent organ of the administration of justice." Id. at 96; see also LANDSMAN, supra note 162, at 48-51 (same); Feeley, supra note 160 , at 754 (contrasting the adversary system with the inquisitorial system).

258. For instance, Justice Scalia, in a dissent from the enactment of the Rule 26 amendments joined by Justices Souter and Thomas, argued:

The proposed new regime does not fit comfortably within the American judicial system, which relies on adversarial litigation to develop the facts before a neutral decisionmaker. By placing upon lawyers the obligation to disclose imformation damaging to their clients-on their own initiative, and in a context where the lines between what must be disclosed and what need not be disclosed are not clear but require the exercise of considerable judgment - the new Rule would place intolerable strain upon lawyers' ethical duty to represent their clients and not to assist the opposing side.

Amendments to the Federal Rules of Civil Procedure, 113 S. Ct. 475, 585 (interim ed. 1993) (Scalia, J., dissenting). See also Denis F. McLaughlin, New Federal Rules of Civil Procedure, N.J. LAw., Jan. 10, 1994, at 1 ("[T]he concern is that attorneys feel compromised in their role as advocates in an adversary system if required to disclose, in the first instance, information damaging to their clients even though they recognize that, upon request, they would be required to divulge the same information in discovery.")

The legal community responded to the Rule 26 disclosure proposal with the most commentary in the history of the Federal Rules of Civil Procedure, with almost all of the commentary harshly critical. See Griffin B. Bell et al., Automatic Disclosure in Discovery-The Rush to Reform, 27 GA. L. REv. 1, 28 (1992) (noting that the proposed changes to Rule 26 "triggered a storm of criticism"); Randall Samborn, U.S. Civil Procedure Revisited: Committee Debates Further Amendments, NAT'L L.J., May 4, 
taken advantage of the rule's opt-out provision and thus have declined to institute the mandatory disclosure. ${ }^{259}$

Further, the lawyer's zealous representation, so prized in the criminal realm, is also highly valued in civil litigation. Indeed, most of those who comment on the role of the lawyer fail to distinguish between civil and criminal litigation. Although I noted above that certain ethical standards will depend on whether the lawyer is practicing in the criminal or the civil realm, these distinctions are the exception, not the norm. In fact, the 1969 Model Code states that "the Disciplinary Rules should be umiformly applied to all lawyers, regardless of the nature of their professional activities."260 While the 1983 Model Rules do make a greater effort to distinguish between different practice areas, ${ }^{261}$ they make no general distinction between lawyers engaged in criminal litigation and those engaged in civil litigation.

Finally, constitutional due process guarantees inform civil as well as criminal adjudication, and these, like the constitutional guarantees discussed in the context of criminal litigation, can also be seen as reflecting the autonomous, distinct role of the citizen. To satisfy due process in the judicial context, the citizen must normally be afforded an opportunity to be heard before a decision is made that will affect his rights or legally protected interests. ${ }^{262}$ "The protection of the due process clause is the protection of individual liberty - a condition of liberal citizenship in which the significance of interests is individually determined."263 Thus, "the prohibition against the deprivation of property without due process of law reflects the high value, embedded in our constitutional and political history, that we place on a person's right to enjoy what is his, free of governmental interference."264 Like the Fourth Amendment warrant requirement, then, the Due

1992, at 1,12 (noting the large number of negative responses to the mandatory disclosure proposal); Carl Tobias, The Back-Door Route for Changing Federal Discovery Rules, ReCORDER, Fcb. 3, 1994, at 8 ("Indeed throughout the rule-revision process, practically all segments of the organized bar, including plaintiffs [sic] lawyers, defense counsel, civil rights attorneys, and public interest practitioners, had strongly opposed the proposal.").

259. See, e.g., P. Kevin Castel, Commercial Litigators Focus on Federal Rules, N.Y. L.J., Jan. 24, 1994, at S4 (Southern District of New York); Living with Rule 26, N.J. LAw., Jan. 10, 1994, at 6 (Northern District of Illinois); James A. Young \& Mary E. Nepps, New Rules Change Federal Practice: But Not All Provisions in Effect in Eastern District, Legal. INTELLIGENCER, Fcb. 2, 1994, at 3 (Eastcrn District of Pennsylvania).

260. Model Code of Professional Responsibiurty preliminary statement (1980).

261. For instance, article 2 of the Model Rules is addressed to the lawyer acting in the capacity of counselor while article 3 is addressed to the lawyer acting in the capacity of advocate. The Model Rules also address specific provisions to lawyers representing organizations, see MODEL RULES of Professional Conduct Rule 1.13 (1983), and lawyers who act as intermediaries between two clicnts, see id. Rule 2.2.

262. Edward D. Re, Due Process, Judicial Review, and the Rights of the Individual, 39 CLEv. ST. L. Rev. 1, 5 (1991).

263. Jerry L. Mashaw, Dignitary Process: A Political Psychology of Liberal Democratic Citizenship, 39 U. FLA. L. REv. 433, 439 (1987).

264. Fuentes v. Shevin, 407 U.S. 67, 81 (1972). 
Process Clause prohibits the state from entering the realm of the citizen unless it provides specific safeguards. ${ }^{265}$

The way in which a legal system is structured depends on the system's conception of the citizen and the citizen's relationship with the state. ${ }^{266}$ This Part has suggested that the adversary system, especially in criminal adjudication, but also to some extent in civil adjudication, is structured to comport with our democratic presumption of citizen autonomy. Accordingly, the traditional role of the lawyer, defined by the adversary system, also presumes autonomous citizens. And if it is the model of the autonomous citizen that gives rise to the lawyer's role as we have traditionally understood it, then if we redefine the role of the citizen in the adjudicatory system, we will also redefine the role of the lawyer. The next Part suggests that that is precisely what the OTS system has done.

\section{VI}

\section{OtS's Conception of the Regulated Person}

Part V suggested that the traditional role of the lawyer is a product of our democratic conception of the citizen and the citizen's relationship with the state. This Part examines the OTS system and concludes that it is premised on a different model of the citizen. Section A will explore this difference by examining OTS regulations in light of the constitutional guarantees that inform the adversary system. As discussed in Part V, these guarantees reflect the citizen's autonomous and distinct role in relation to the state. OTS regulations, however, are highly problematic in light of these guarantees as they are ordinarily interpreted; in fact, OTS regulations frequently fall into doctrinal exceptions to the constitutional norms. With this information, Section B goes on to explore the alternative conception of the citizen that is reflected in the OTS system.

\section{A. The OTS System as Inconsistent with the Constitutional Guarantees Informing the Adversary System}

\section{The Privilege Against Self-Incrimination and The Fourth Amendment}

The two key regulations in the Kaye Scholer case ${ }^{267}$ are both problematic in light of the privilege against self-incrimination as it is ordinarily understood. ${ }^{268} 12$ C.F.R. $\$ 563.170(\mathrm{c})$ requires thrifts to establish and maintain business records and make those records available to OTS examiners. It is of no matter that the records might contain incriminating evidence. 12 C.F.R. $\$ 563.180$ requires thrifts to report periodically to OTS

265. Cheh, supra note 245 , at 1369 (noting that "[c]ivil procedural due process, while not as cxtensive as criminal law procedural protections, does impose significant safeguards against arbitrary, oppressive, or erroneous action").

266. See Post, supra note 212 , at 672 .

267. 12 C.F.R. $\S \S 563.170, .180$ (1993).

268. See supra notes $219-31$ and accompanying text. 
about their affairs, ${ }^{269}$ and they must include in those reports all material facts regarding all matters in OTS's jurisdiction. ${ }^{270}$ Thus, under OTS's scheme, thrifts may be required by regulation to incriminate themselves. In fact, OTS regulations extend beyond merely denying thrifts their privilege against self-incrimination. The privilege enables citizens to refuse to answer questions when the answers would tend to be incriminating. OTS regulations not only require thrifts to answer those same questions but also require them to volunteer incriminating evidence when OTS would find that evidence relevant.

12 C.F.R. $\S 563.170$ is also problematic in light of Fourth Amendment protections. That regulation authorizes OTS to examine and audit thrifts at any time. ${ }^{271}$ These examinations and audits are searches subject to the Fourth Amendment, since they involve the comprehensive scrutiny of thrift documents. Nonetheless, OTS may examine and audit without any showing of probable cause or even individualized suspicion.

Although OTS regulations are clearly in tension with ordinary interpretations of the privilege against self-incrimination and the Fourth Amendment, they would no doubt be held constitutional because they fall within well-established exceptions to the general constitutional rules. The Supreme Court has decided several cases involving record-keeping provisions that are similar to those promulgated by OTS and has held that "under some circumstances a person may be required by law-subject to criminal sanction-to cominunicate in writing with government officials even though the cominunications themselves might be incriminating enough to support a criminal conviction."272 Similarly, certain administrative inspections utilized to enforce regulatory schemes seem to be exempt frons Fourth Amendment protections and nay be authorized sinuply by statute. This exception applies in industries that have a long history of supervision ${ }^{273}$ and in industries that are pervasively regulated. ${ }^{274}$

269. 12 C.F.R. $\$ 563.180$ (a) (1993).

270. Id. $\S 563.180(\mathrm{~b})(1)$.

271. Id. $\S 563.170(\mathrm{a})(2)$.

272. Stephen A. Saltzburg, The Required Records Doctrine: Its Lessons for the Privilege Against Self-Incrimination, 53 U. CH. L. REv. 6, 10 (1986); see Shapiro v. United States, 335 U.S. 1, 32 (1948) (requiring disclosure of records is acceptable "when there is a sufficient relation between the aetivity sought to be regulated and the public concern").

273. See, e.g., Colonnadc Catering Corp. v. United States, 397 U.S. 72, $76-77$ (1970) (liquor industry).

274. See, e.g., Donovan v. Dewey, 452 U.S. 594, 598-604 (1981) (upholding Federal Mine Safcty and Health Act which directed federal officers to inspect underground mines periodically without providing advance notice); United States v. Biswell, 406 U.S. 311, 315 (1972) (firearms industry). It is said that "banking is the most regulated industry in the United States." LASH, supra note 14, at vii; see also WHITE, supra notc 10, at 25 ("among the most heavily regulatcd").

Alternativcly, OTS rcgulations might withstand a Fourth Amendment challenge by means of the "special needs" exception to the Fourth Amendment. The Court has upheld searches that arc not supported by a warrant, probable cause, or even individualized suspicion " 'when "special needs, beyond the normal need for law enforcement, make [those requirements] impracticable." " " Skinner v. 


\section{Due Process}

Several OTS regulations are in tension with due process guarantees. The Due Process Clause generally guarantees that the government will provide citizens with specific safeguards before it deprives them of life, liberty or property. These safeguards reflect the citizen's autonomous and distinct role in our democratic society. I will discuss four aspects of the OTS scheme that fail to incorporate the safeguards normally required by the Due Process Clause.

\section{a. Temporary Cease and Desist Orders: No Predeprivation Hearings}

A central tenet of due process is that persons should have the opportunity to be heard at a meaningful time and in a meaningful manner when their rights are affected. ${ }^{275}$ In almost all cases, courts have interpreted that standard as requiring the government to provide some form of hearing before depriving an individual of a property or liberty interest. ${ }^{276}$ Although a postdeprivation hearing may result in the return of the property or even the payment of damages, "no later hearing and no damage award can undo the fact that the arbitrary taking that was subject to the right of procedural due process has already occurred."277

As noted in Part I, OTS may issue a temporary cease and desist order that freezes a defendant's assets without a prior hearing. ${ }^{278}$ OTS, rather than an administrative law judge, makes all of the factual determinations that are necessary to support these orders. Consequently, Professor Coffee notes that "[i]n this respect, FIRREA deviates from the traditional administrative law model in which a supposedly disinterested party (the ALJ) is interposed between the enforcement agency and the remedy it desires."279 This broad power to seize assets without prior hearing may, in fact, be unique to OTS. A few other administrative agencies have statutory authority to issue temporary cease and desist orders; however, their power is generally more limited than that granted to OTS. ${ }^{280}$ For instance, the SEC may issue a temporary cease and desist order, but the authorizing statutes explicitly state that "[s]uch an order shall be entered only after notice and opportunity for a hearing, unless the Commission determines that notice and

Railway Labor Executives' Ass'n, 489 U.S. 602, 619 (1989) (quoting Griffin v. Wisconsin, 483 U.S. 868,873 (1987) (quoting New Jersey v. T.L.O., 469 U.S. 325, 351 (1985) (Blackmun, J., concurring in the judgment))); see also National Treasury Employees Union v. Von Raab, 489 U.S. 656, 665-66 (1989).

275. Armstrong v. Manzo, 380 U.S. 545, 552 (1965).

276. United States v. James Daniel Good Real Property, 114 S. Ct. 492, 500-01 (1993); see also Wolff v. McDonnell, 418 U.S. 539, 557-58 (1974) (liberty interests entitled to same protection as property).

277. Fuentes v. Shevin, 407 U.S. 67, 82 (1972).

278. 12 U.S.C. $\$ 1818$ (c)(1) (Supp. IV 1992).

279. John C. Coffee, Jr., Due Process for Kaye, Scholer?, Legal Tmes, Mar. 16, 1992, at 22.

280. Nussbaum \& Stern, supra note 154 , at 1. 
hearing prior to entry would be impracticable or contrary to the public interest."281 The legislative history emphasizes that Congress "views a temporary cease-and-desist order entered on an ex parte basis as an extraordinary remedy."282

Here again, OTS's powers fall into an exception to the general rule. Although due process ordinarily requires the government to provide a hearing before depriving a citizen of property, certain "extraordinary situations" justify postponing the hearing until after the deprivation. ${ }^{283}$ In Federal Deposit Insurance Corp. v. Mallen ${ }^{284}$ the Supreme Court held that "[a]n important government interest, accompanied by a substantial assurance that the deprivation is not baseless or unwarranted, may in limited cases demanding prompt action justify postponing the opportunity to be heard until after the initial deprivation."285 When applying this test to cases involving thrift officers and directors, subsequent courts have had little difficulty upholding OTS's temporary cease and desist orders. ${ }^{286}$

\section{b. Conservatorship and Receivership Provisions: Limited Judicial Review}

OTS may seize thrifts, without notice or hearing, and place them under conservatorship or into receivership. ${ }^{287}$ Since defendants are provided no predeprivation hearings, these provisions raise the same due process concerns discussed above in the context of temporary cease and desist orders. What is more, the conservatorship and receivership provisions raise additional due process concerus because subsequent judicial review of OTS action is often extremely limited.

After OTS seizes a thrift, the thrift owner has only one remedy: to apply to a federal district court for judicial review of OTS's decision. ${ }^{288}$ In order to prevail, thrift owners must normally show that OTS's action was

281. 15 U.S.C. § 77h-1(c)(1) (Supp. IV 1992); see also id. § 78u-3(c)(1) (identical text); id. § 80a$9(\mathrm{f})(3)(\mathrm{A})$ (substantially identical text); $i d . \$ 80 \mathrm{~b}-3(\mathrm{k})(3)(\mathrm{A})$ (same).

282. H.R. REP. No. 616, 101 st Cong., $2 \mathrm{~d}$ Sess. 25 (1990), reprinted in 1990 U.S.C.C.A.N. 1379, 1392.

283. Boddie v. Connecticut, 401 U.S. 371,379 (1971).

284. 486 U.S. 230 (1988).

285. Id. at 240 .

286. For instance, in Spiegel v. Ryan, 946 F.2d 1435 (9th Cir. 1991), cert. denied, 112 S. Ct. 1584 (1992), the Ninth Circuit upheld an OTS temporary cease and desist order, finding that Congress has an important interest in fighting insider abuse of savings institutions, and that by authorizing temporary cease and desist orders, Congress acknowledged a need for prompt action. Id. at 1440. Finally, the court found that the temporary cease and desist order provided "substantial assurance" that the charges were not "baseless or unwarranted" because it set forth detailed findings regarding Spiegel's misconduct based on examinations. Id.; see also Paul v. OTS, 763 F. Supp. 568 (S.D. Fla. 1990), aff'd without opinion sub nom. Paul v. Ryan, 948 F.2d 1297 (11th Cir. 1991).

287. I2 U.S.C § 1464(d)(2)(B) (Supp. IV 1992).

288. Id. 
arbitrary and capricious. ${ }^{289}$ Under this standard, OTS's decision is entitled to a presumption of "regularity",290 administrative action is considered arbitrary and capricious only where it is not supportable on any rational basis. ${ }^{291}$ Moreover, although some courts have held that a thrift owner is entitled to a full evidentiary trial following a takeover by OTS, ${ }^{292}$ others restrict judicial review to the administrative record. ${ }^{293}$ In the latter courts, the thrift owners cannot present any evidence or examine any witnesses. ${ }^{294}$ OTS gathers what it determines to be the administrative record and turns it over to the court. ${ }^{295}$ Based on this record alone, the judge decides whether OTS's action was arbitrary or capricious. ${ }^{296}$ Not surprisingly, given these standards and procedures, neither OTS nor its predecessor the FHLBB has ever lost a conservatorship case. ${ }^{297}$

\section{c. Capital Directives: No Judicial Review}

As noted in Part $I,{ }^{298}$ capital directives are orders that require thrifts to take specified steps in order to bring capital levels up to a previously established standard. OTS begins a capital directive enforcement process by issuing a notice of intent to inipose a capital directive. The thrift may respond to the notice by presenting "information, mitigating circumstances, docunientation or other relevant evidence supporting the [thrift]'s position." ${ }^{299}$ However, this is the thrift's only formal opportunity to respond to OTS. ${ }^{300}$ Thereafter, OTS will decide whether to issue the capital directive,

289. Franklin Sav. Ass'n v. OTS, 934 F.2d 1127, 1141-42 (10th Cir. 1991), cert. denied, 112 S. Ct. 1475 (1992); Woods v. FHLBB, 826 F.2d 1400, 1408 (5th Cir. 1987), cert. denied, 485 U.S. 959 (1988); Guaranty Sav. \& Loan Ass'n v. FHLBB, 794 F.2d 1339, 1342 (8th Cir. 1986).

290. Franklin Sav. Ass'n, 934 F.2d at 1141.

291. San Marino Sav. \& Loan Ass'n v. FHLBB, 605 F. Supp. 502, 508 (C.D. Cal. 1984).

292. E.g., Haralson v. FHLBB, 655 F. Supp. 1550, 1559-60 (D.D.C. 1987), appeal dismissed, 837 F.2d 1123 (D.C. Cir. 1988); Fidelity Sav. \& Loan Ass'n v. FHLBB, 540 F. Supp. 1374, 1377-78 (N.D. Cal.), rev'd on other grounds, 689 F.2d 803 (9th Cir. 1982), cert. denied, 461 U.S. 914 (1983); Telegraph Sav. \& Loan Ass'n v. FSLIC, 564 F. Supp. 862, 869 (N.D. Ill. 1981) see also Collie v. FHLBB, 642 F. Supp. 1147, 1151-52 (N.D. Ill. 1986) (requiring hearing unless thrift "has had a meaningful opportunity to make a case in opposition to the appointment of a receiver at some point during the process leading to the appointment").

293. Franklin Sav. Ass'n, 934 F.2d at 1142; Woods, 826 F.2d at 1408; Guaranty Sav. \& Loan, 794 F.2d at 1342.

294. See, e.g., Franklin Sav. Ass'n, 934 F.2d at 1139-40.

295. See, e.g., id.

296. See, e.g., id. at 1142.

297. William W. Mahood III, Comment, Due Process Considerations in the Federal Takeover of Savings and Loan Associations: The Case for a Hybrid Manner of Review, 40 KAN. L. REv. 1065, 1072 (1992); see also Biscayne Fed. Sav. \& Loan Ass'n v. FHLBB, 572 F. Supp. 997, 1047 (S.D. Fla.) ("[T] he few courts which have dealt with this statute over its fifty-year history have never restored an insolvent institution to the association."), rev'd and vacated in part, aff'd in part, 720 F.2d 1499 (11th Cir. 1983), cert. denied, 467 U.S. 1215 (1984).

298. See supra text accompanying notes 104-12.

299. Daniel B. Gail, Without Due Process: The Use of Capital Directives to Enforce Bank Capital Rules, 46 CONSUMER Fin. L.Q. REP. 214, 215 (1992).

300. Id. 
and the agency has flexible, virtually unfettered authority to craft directives and to require corrective measures and affirmative actions as it deems necessary to ensure that undercapitalized thrifts reach and maintain minimum capital levels. ${ }^{301}$

Even though a capital directive is enforceable to the same extent as an effective and outstanding final cease and desist order, ${ }^{302}$ the statute authorizing capital directives does not provide for judicial review of agency action. $^{303}$ After examining the statute, the Fifth Circuit held that a capital directive is completely unreviewable in the courts. ${ }^{304}$ Thus, a thrift is provided no hearing on the record and no opportunity to cross-examine agency officials about their conclusions. ${ }^{305}$

\section{d. OTS's Adjudicatory Proceedings}

The above three subsections detail specific regulations that are problematic in light of the Due Process Clause. In addition to those specific provisions, OTS's adjudicatory structure raises due process concerns. First, the administrative law judge (ALJ) in OTS cases may not be sufficiently disinterested; and second, even if the ALJ is disinterested, it might be a moot point because the Director of OTS has substantial independent authority over the adjudication.

1) Disinterested decisionmaker. As noted above, the Due Process Clause requires the state to provide certain safeguards before depriving citizens of life, liberty or property. One such safeguard is a neutral decisionmaker. $^{306}$ ALJs in OTS proceedings are employees of OTS ${ }^{307}$ and therefore may be too closely associated with the agency to be sufficiently neutral. Of course, Harris Weinstein, former OTS chief counsel, has maintained that although ALJs are OTS employees, OTS keeps its prosecutorial and adjudicatory functions rigidly separate. "The two groups of people are not allowed to talk to each other."308 However, even if the examiners and prosecutors do not associate with the ALJs, the Director of OTS certainly does associate with the ALJs, as the following subsection details.

Moreover, even if the ALJs' functions are kept separate from other OTS departments, we still may fear that ALJs can be subtly influenced simply because the ALJs are OTS enployees. After all, ALJs have none of the salary or tenure protections that Article III judges enjoy, protections that are

301. Id. at 216 .

302. 12 U.S.C. $\$ 1464(s)(4)(B)$ (Supp. IV 1992).

303. 12 U.S.C. $\$ 3907$ (1988).

304. FDIC v. Bank of Coushatta, 930 F.2d 1122, 1125-29 (5th Cir.), cert. denied, 112 S. Ct. 170

(1991).

305. Gail, supra note 299 , at 217.

306. See supra note 238 and accompanying text.

307. See Gillers \& Simon, supra note 3, at 730.

308. DeBenedictis, supra note 127 , at 59 (quoting Harris Weinstein of OTS). 
designed to insulate judges from political and economic pressures. ${ }^{309}$ An American Bar Association task force study supports concerns over ALJ partiality. The ABA task force studied Securities and Exchange Commission administrative hearings over a five-year period and found that the SEC ALJs upheld the SEC in 58 of 62 cases. $^{310}$

2) The OTS Director's involvement. Even if OTS ALJs are wholly disinterested, impartial decisionmakers, it may not matter because their role in adjudications may be overshadowed by the Director of OTS. ALJs at OTS have no power to dismiss an action or rule on any motion that will result in the final determination of the suit. Only the Director of OTS has that authority. ${ }^{311}$ Moreover, after hearing the evidence, the ALJ makes findings of fact, but instead of issuing a judgment, the ALJ merely issues a recommended decision to OTS. The Director of OTS has substantial discretion to adopt, reject or modify the ALJ's decision. ${ }^{312}$ Thus, the Director of OTS, the same person who signs the complaint against the defendant, has the final say over the determination of the matter. ${ }^{313}$

The ALJ's arguable lack of impartiality and the Director's involvement in shaping the administrative record might not be so unsettling if cases were subsequently entitled to broad review in Article III courts. ${ }^{314}$ But just the opposite is true: review in Article III courts tends to be quite narrow. Article III courts rarely, if ever, review cases de novo; instead they must sustain the agency's findings if they are supported by substantial evidence in the record as a whole. ${ }^{315}$ And the agency's choice of remedy will not be disturbed unless it is an abuse of discretion or is otherwise arbitrary or

309. Gillers \& Simon, supra note 3, at 730; see also Re, supra note 262 , at 3.

310. See ABA Task Force Survey Finds ALJS Almost Always Uphold SEC Charges, 21 Sec. Reg. \& L. Rep. (BNA) at 1531 (Oct. 13, 1989).

311. 12 C.F.R. $\S 509.5(b)(7)$ (1993).

312. See, e.g., id. $\S \S 509.4, .39, .40 ; c f$. Central Nat'1 Bank v. United States Dep't of Treasury, 912 F.2d 897, 904-05 (7th Cir. 1990) (justifying grant of discretion to Comptroller of the Currency and not ALJs).

313. Kaye Scholer's counsel, Bernard Nussbaum, has repeatedly denounced this aspect of Kaye Scholer's litigation with OTS. He has maintained that OTS is, in effect, bringing a case before itself. "Tim Ryan [Director of OTS] is the prosecutor, he held the press conference, and he's the judge. He will decide whether his complaint is warranted or not." Symposium, supra note 6, at 66 . Monroe Freedman made a similar point when he railed against the danger of the SEC instituting its own disciplinary proceedings against attomeys. Freedman, LAwYers' Ethics, supra note 169, at 20-24. "When the SEC seeks to discipline an attorney, it acts not as a disinterested third party, but as a partisan." Id. at 23.

Although OTS is certainly not the only administrative agency empowered to judge the merits of actions brought by agency personnel, Professor Koniak observed that

this commonplace practice is troubling because allowing state actors to bring charges, to try a defendant, and to render a "verdict" provides those actors with the power to insist on a legal vision that courts might not ratify; defendants might be coerced to give in when faced with this concentration of power.

Koniak, supra note 181, at 1105 (footnote omitted).

314. See Richard H. Fallon, Jr., Of Legislative Courts, Administrative Agencies, and Article III, 101

HARV. L. REV. 915 (1988) (advocating searching reviews of administrative agency decisions).

315. Akin v. OTS, 950 F.2d 1180, 1183 (5th Cir. 1992) (applying 5 U.S.C. $\S 706(2)$ ). 
capricious..$^{316}$ These standards are problematic from a due process perspective simply because the Director of OTS has so much control over shaping the record as a whole.

\section{B. OTS and the Managed Citizen}

The constitutional guarantees that inform the adversary system act as barriers to state action; they are designed to limit the state's power over citizens. The Supreme Court has understood these guarantees as acknowledging the citizen's private interests and objectives, and thus reflecting our democratic ascription of citizen autonomy. That the OTS system fails to incorporate these restraints on state action suggests that the OTS system does not understand the people it regulates to be autonomous citizens but rather views them instrumentally as means for achieving specific governmental goals.

What one immediately notices when contrasting the OTS system with the adversary system is the efficiency of the OTS system. From an instrumental perspective, the constitutional guarantees and other distinctive features that characterize the adversary system are inefficient because they impede the government's ability to achieve its legitimate regulatory goals. ${ }^{317}$ For instance, although prevention and punishment of crime is widely accepted as vital to the public interest, the government does not have free rein to pursue that objective. The citizen is seen as having private interests and objectives which must be acknowledged and respected.

By contrast, since the OTS system is not hampered by the traditional constitutional norms, it is free to pursue its own goals efficiently, without considering the citizen's independent objectives. OTS can be seen, then, as regulating thrifts by means of what Professor Post has called "managerial authority."318 Managerial authority presupposes a realm of instrumental reason; that is, a managerial system is one that takes the pre-established goals of the system as given and seeks to manipulate the available resources to attain those pre-established ends. As Professor Selznick phrased it, " 'Management' suggests rational, efficiency-minded, goal-driven organization. . . . Ends are characteristically taken as given, and every act is justified by the contribution it makes to those ends. All else is a distraction."319

Orgamizations, for example, typically regulate their members managerially. Orgamizations are goal-oriented; that is, they are "formally estab-

316. Id.; see also supra note 85.

317. "The criminal procedural protections set out in the Constitution are extremely costly and time consuming. In fact, they may add nothing to and even frustrate the goals of faimess, accuracy, and truth-finding." Cheh, supra note 245, at 1351.

318. Robert C. Post, Between Governance and Management: The History and Theory of the Public Forum, 34 UCLA L. REv. 1713, 1775 (1987) [hereinafter Post, Between Governance]; Post, stupra note 212 , at 658 .

319. Philip Selzntck, The Moral Commonwealth: Soctal Theory and the Promise op СоммuNITY 289-90 (1992). 
lished for the explicit purpose of achieving certain goals."320 The organizational goals are taken as value premises, and the function of the organization is to implenient these premises, ${ }^{321}$ preferably by the most efficient means available. ${ }^{322}$ Organizations seek to arrange and manipulate their resources, including their hunian resources, so as to achieve their institutional ends most efficiently. ${ }^{323}$ To that end, organizations typically distribute various tasks anıong various positions in the organization. ${ }^{324}$ So, for example, a school system will arrange administrators, faculty, faculty support, library staff, and miscellaneous other individuals to attain its goal of educating students.

An individual's role in an organization is functionally defined by the organization's needs. ${ }^{325}$ As members of the organization, individuals are expected to subordinate their personal goals in order to achieve the organization's goals." ${ }^{326}$ "Organizations thus strive to ensure that 'their personnel should not be influenced by extra-organizational factors,' and they attempt functionally to define for their members specifically organizational roles that predominate over the multiple roles and statuses characteristic of the general society."327

This discussion of organizations is apposite to the OTS system because OTS regulates thrifts in the same way that an organization regulates its members. ${ }^{328}$ In respouse to the S\&L crisis, Congress bestowed on OTS significant control over all aspects of thrift practice-over everything from

320. Peter M. Blau \& W. Richard Scott, Formal Organtzations: A Comparative Approach 5 (1962); Talcott Parsons, Suggestions for a Sociological Approach to the Theory of Organizations-I, 1 ADMIN. SCI. Q. 63, 64 (1956) ("As a formal analytical point of reference, primacy of orientation to the attainment of a specific goal is used as the defining characteristic of an organization which distinguishes

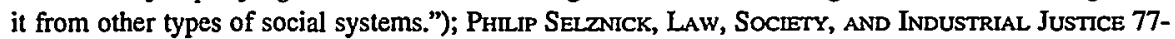
78 (1969).

321. Post, Between Governance, supra note 318, at 1788.

322. BlAU \& Scotr, supra note 320 , at 49.

323. Post, Between Governance, supra note 318, at 1767.

324. From MAX Weber: Essays in Sociology 196 (H.H. Gerth \& C. Wright Mills trans. \& eds., 1946); Parsons, supra note 320, at 68 (describing a "more familiar approach to the structure of an organization ... through its constituent personnel and the roles they play in its functioning"); see also id. at 77 (describing the internal allocation of an organization's resources).

325. See Post, Between Governance, supra note 318, at 1792; see also Parsons, supra note 320, at 67 (an organization's value pattern "defines the basic orientation of the . . organization" and "guides the activities of participant individuals").

326. "The organization is constituted by formal offices and rules connecting them. People are secondary, in that they merely fill the offices, enacting their formal requirements and carrying out specified rules and fulfilling preexisting expectations." MEIR DAN-CoHEN, Rights, Persons, AND Organizations 34-35 (1986); see also SELZNICK, supra note 320, at 78 (describing Max Weber's view that the "parts" of a bureaucratic organization are "offices, not persons").

327. Post, Between Governance, supra note 318, at 1792-93 (footnotes omitted) (quoting CHARLES B. Perrow, Organizational Analysis: A Sociological View 51 (1970)). As Professor Parsons put it, the focus of an organization's value system must be the "legitimation of the primacy of this goal over other possible interests and values of the organization and its members." Parsons, supra note 320, at 68.

328. An alternative way of getting at this same idea might be to say that OTS regulates thrifts in the same way that it regulates its own employees. 
capitalization ${ }^{329}$ to personnel decisions. ${ }^{330}$ This control is not mediated by the constitutional guarantees discussed above, guarantees that require the government to take account of the citizen's independent objectives. Rather, the OTS system is structured on the assumption that thrifts have no independent objectives. ${ }^{331}$ The role of the thrift in the OTS system is functionally defined by OTS's regulatory goals. So instead of viewing the thrift as occupying a realm that is distinct from the state's realm, OTS regards the thrift as enveloped within OTS's instrumental orientation.

OTS's controversial reporting and disclosure requirements provide a nice example of the way that OTS defines the thrift's role in terms of its own regulatory needs. OTS's primary institutional goal is to ensure a strong, viable thrift industry. ${ }^{332}$ To achieve this, OTS must promulgate substantive rules which, if obeyed, will produce the desired results. But, as any law enforcement officer knows, substantive legal rules may not be enough; to carry out its mission in the most efficient way, OTS must also have the means to determine when thrifts are violating the rules. Not surprisingly, then, OTS regulations require that thrifts provide it with this necessary information. Thrifts must submit to periodic examinations. Thrifts must establish and maintain records and make them available whenever OTS might ask for them. Thrifts and their agents must report to OTS and disclose all material facts concerning all matters within OTS's jurisdiction. Any interest that a thrift might have in keeping this information confidential is subordinated to OTS's need to achieve its regulatory goals.

Moreover, because its need to achieve its goals is paramount, OTS must similarly manage the lawyers who represent thrifts. Accordingly, the Notice of Charges and the resulting Settlement Order in the Kaye Scholer case can be seen as OTS's attempt to define the lawyer's role as one which advances OTS's objectives. Lawyers must volunteer facts that are adverse or irrelevant to their theory of the case if they suspect that OTS has a differ-

329. See supra text accompanying notes 104-12.

330. See supra text accompanying notes 53-59.

331. OTS never speaks of imposing its goals on thrifts; rather, it simply assumes that thrifts share its goals. A speech given by OTS Regional Director Eric Shand to the California League of Savings Institutions (on file with author) provides a fine example of this. Mr. Shand's short specch, the transcript of which is only eight double-spaced pages, referred no less than six times to the common interests and common goals shared by OTS and the thrifts. See also John Burke, The Examiners are Coming, Outrook Fed. Home Loan Bank SYs., Jan./Feb. 1987, at 4, 6 (referring to the "common-goal approach" to thrift examination).

332. Robert Cooper, Note, The Office of Thrift Supervision, 59 FordHAM L. REv. S363, S368 (1991); see also 12 U.S.C § 1463(a)(1) (Supp. IV 1992) (the Director of OTS is to "provide for the examination, safe and sound operation, and regulation of savings associations"). For a discussion of banking regulatory goals in general, see Kenneth Spong, Banking Regulation: Its Purposes, IMPLEMENTATION, AND EFFeCTS 5-12 (1983); LASH, supra note 14, at 22-26.

Of course this discussion assumes OTS's stated goals. There may be a great divergence between an organization's stated goals and its "opcrational" or "reflexive" goals. See, e.g., WARREN B. BROWN \& Denmis J. Moberg, Organization Theory and Management: A Macro Approach $239-43$ (1980); DAN-CoHeN, supra note 326, at 36-38. 
ent theory of the case. Moreover, lawyers cannot represent any thrift that is attempting to evade even the spirit of the banking regulations by placing form over substance. The obligations that OTS imposes on lawyers preclude them from assuming any role but that which furthers OTS's regulatory goals. ${ }^{333}$

Because the OTS system regulates thrifts and their lawyers managerially, the adversarial nature of adjudication that we are accustomed to in the adversary system is sharply diminislied in the OTS system. The OTS system contemplates that the thrift, its lawyers and OTS will all work together in pursuit of a common, pre-established goal. OTS's goals are seen as controlling, and the need to achieve those goals justifies OTS's manipulation of all available resources, including thrifts and their lawyers.

Needless to say, the assumptions underlying the OTS system are in sharp contrast with those on which our democratic self-government is based. ${ }^{334}$ Democracy envisions autonomous citizens who clioose their own goals. "Autonomy requires that ends as well as means be developed from within, not imposed from without." 335 Therefore, while democracy constitutes autonomous citizens, managerial authority creates "subjects."336 As Professor Selznick put it, "People subject to managerial direction may be thought of as interchangeable, deployable, expendable units, to be used or discarded as efficiency may require." ${ }^{\prime 337}$ Professor Post similarly described the contrast thus:

Managerial structures locate citizens within the constraints of instrumental reason, assuming therefore that citizens are objects of regulation, subject to the laws of cause and effect. Structures of self-governance, in contrast, situate citizens within webs of herme-

333. Moreover, the Settlement Order does not define the lawyer's role solely by regulating the lawyer's obligations; it does so also by subtly seeking to align the lawyer's interests with its own. For instance, the Settlement Order requires that Kaye Seholer appoint a banking partner with at least ten years experience to supervise the representation of an insured depository institution. Settlement Order, supra note 145, para. 4. Although this requirement may be designed primarily to ensure that thrifts receive competent advice, the requirement also serves to align Kaye Scholer's interests with OTS's, and it thereby increases the likelihood that Kaye Scholer will function within the role that OTS has defined for it. A banking lawyer with ten years experience has a large investment in her career as a banking lawyer. She will typically be very concerned about her reputation with the banking agencies, and for that reason she may be less likely to become overly aggressive with the agency on behalf of any one client. In contrast to Peter Fishbein, who can fall back on a general litigation practice, a banking lawyer's career might be completely ruined if she were barred from practicing before the banking agencies.

334. Professor Cohen observes that heteronomous structures, such as the military, "are intensely antithetical to democracy." CoHEN, supra note 206, at 271.

335. Id.

336. Id. at 272. "[T]he citizen, in a heteronomous govemment, is most fundamentally the instrument of another, a tool for the accomplishment of some higher purpose imposed from without." Id. at 271.

337. SelZNICK, supra note 319, at 290. 
neutic interactions, assuming therefore that citizens are autonomous and self-determining. ${ }^{338}$

Given the foregoing account, it is not surprising that the OTS system and the adversary system place different obligations on lawyers. The nature of any legal system will depend "upon whether [it is] intended to foster interactions among citizens who are autonomous or, instead, among citizens who are not." 339 Traditional legal ethics rules reflect the adversary system's presumption of autonomous citizens. The traditional lawyer's zealous partisanship and strict duty of confidentiality, for example, express respect for the citizen's independent interests. The OTS system, by contrast, presupposes a managed citizen, an entity to be nianipulated for a specified purpose. The OTS system is structured so as to preclude recognition of the citizen's independent interests; thus, the above-mentioned features of the traditional lawyer's role can have no place in such a system.

The Kaye Scholer controversy, then, involves much more than a dispute over legal ethics rules and the appropriate role of the lawyer. What is at stake in the Kaye Scholer controversy is the citizen's role and relationship with the state.

\section{VII}

\section{Concluding Thoughts}

This Comment has suggested that a useful way to understand the Kaye Scholer controversy is to view the conflicting obligations confronting Kaye Scholer as refiecting different conceptions of the role of the citizen. This Comment has not, however, examined the normative question implicit in the discussion: in what domains do we want to subject citizens to managerial authority? Such an inquiry is beyond the scope of the Comment; however, this Part will explore some considerations that might be relevant in assessing the desirability of the OTS system.

We might find the OTS system acceptable because it primarily regulates corporations, not individuals. Our legal system already distinguishes between citizens and corporations, at least to some extent. For instance, the privilege against self-incrimination has never been available to corporations. $^{340}$ One might argue more broadly, as Professor Meir Dan-Cohen has, that legal rules derived from notions of autonomy should have only very limited application to organizations such as corporations. He reaches this

338. Post, supra note 212 , at 673 . Professor Selznick similarly contrasts management and governance. See SElzNicK, supra note 319, at 289-90.

339. Post, supra note 212 , at 672 . "From the point of view of the designer of the structure, therefore, the presence or absence of autonomy functions as an axiomatic and foundational principle." Id. at 672-73.

340. See, e.g., Bellis v. United States, 417 U.S. 85, 89-90 (1974); United States v. White, 322 U.S. 694,699 (1944) ("Since the privilege against self-incrimination is a purely personal one, it cannot be utilized by or on behalf of any organization, such as a corporation."); Hale v. Henkel, 201 U.S. 43, 69. 70 (1906). 
conclusion after observing that organizations should not be identified with their members because they have different goals, ${ }^{341}$ so that reference to members' autonomy rights can only justify very limited autonomy rights for organizations. ${ }^{342}$ Hence, even though a democracy must ascribe autonomy to its individual citizens, it may not need to extend the status of citizen to legally established entities such as corporations.

If corporations themselves do not command the status of citizen, then managerially regulating the corporation's members poses little problem. Members of a corporation are already subject to the corporation's instrumental orientation and managerial authority. This perspective might lead one to conclude that the OTS system is not redefining citizens as managed subjects; rather, OTS takes persons who have already been placed in functionally defined roles and merely reshapes those roles in accordance with OTS's regulatory objectives. Thrift owners, outside of their corporate capacity, can still enjoy the wide variety of roles characteristic of autonomous citizens. ${ }^{343}$

Another reason we might feel justified in imposing managerial authority on thrifts is because OTS suits are usually civil actions. As noted in Part $\mathrm{V},{ }^{344}$ civil litigation does not present a clear picture of the autonomous citizen; instead it incorporates managerial features that modify the autonomous role of the citizen when doing so is necessary to further its goal of administering justice efficiently. Thus, to the extent that OTS suits can justifiably be labeled civil, one can argue that the OTS system does not present so radical a departure from adversarial norms.

However, the distinction between civil cases and criminal cases tends to blur in the OTS context. ${ }^{345}$ Although suits brought against thrifts are technically civil suits, they nevertheless raise many of the same concerns that arise in the criminal context. An OTS suit, like a criminal action, pits the citizen against the coercive power of the state. ${ }^{346}$ Additionally, the pen-

341. DAN-COHEN, supra note 326 , at 38.

342. Id. at 77-78.

343. See, e.g., Resolution Trust Corp v. Walde, 18 F.3d 943 (D.C. Cir. 1994). In Walde, the District Court of Columbia Circuit held that, absent some evidence that a former officer or director of a failed S\&L is liable to the S\&L, the Resolution Trust Corporation does not have authority to subpoena personal financial information from the former officer or director for the sole purpose of determining whether that person has sufficient net wealth to warrant suing. Id. at 949 . The court distinguished between subpoenas seeking corporate records and those seeking personal records, stating that " 'corporations can claim no equality with individuals in the enjoyment of a right to privacy.' " Id. at 948 (quoting United States v. Morton Salt Co., 338 U.S. 632, 652 (1950)).

344. See supra text accompanying notes 245-66.

345. For a general discussion on the difficulty of distinguishing between civil and criminal law, see Cheh, supra note 245, at 1348-69; Jonathan I. Charney, The Need for Constitutional Protections for Defendants in Civil Penalty Cases, 59 Cornell L. Rev. 478, 491-506 (1974).

346. However, the resemblance between an OTS defendant and a defendant in an ordinary criminal case may be slight. The typical criminal defendant is an impoverished social outcast. The typical OTS defendant is more likely to be a sophisticated business person with considerable resources. Cf. David B. Wilkins, Who Should Regulate Lawyers?, 105 HARv. L. REv. 801,819 (1992) (noting that the 
alties for violating certain regulations might be seen as resembling penal sanctions. ${ }^{347}$ For instance, under its three-tier civil money penalty structure, OTS may assess a penalty of up to $\$ 1$ million per day on thrifts that knowingly commit certain violations. ${ }^{348}$ Sanctions of $\$ 1$ million per day for "knowing" offenses are arguably punitive. ${ }^{349}$ Thus, in many ways OTS suits look less like civil litigation, which is concerned with administering justice between the parties, and more like criminal litigation, which constitutes the citizen's relationship with the state.

Resemblances between an OTS proceeding and a criminal proceeding might counsel against subjecting thrifts to managerial authority. Criminal adjudication defines the relationship between the citizen and the state, and in keeping with our democratic ascription of citizen autonomy, it is where we are at greatest pains to limit the government's use of instrumental rationality over citizens. Moreover, autonomy is seen as especially important in criminal proceedings because the stakes for the defendant are so high and the interests of the parties are so divergent. Managerial systems, by contrast, are premised on the notion that the system's goals are shared by all those subject to the system's authority. Of course, phrasing the propositions in that way presupposes that individuals can properly have interests independent of the regulatory system's interests. That phrasing, then, is presumptuous since the question that we are seeking to answer is the antecedent question of when we want to permit the state to regulate persons as though such divergent interests do not exist. Nonetheless, one consideration in assessing the desirability of imposing managerial authority in a particular domain may be the extent to which that imposition alters cherished beliefs about personhood and social roles. Imposing managerial authority in the criminal arena may represent too sharp a divergence from traditional conceptions, so that to the extent OTS proceedings resemble criminal proceedings we may wish to be cautious in approving the OTS managerial regime.

Perhaps the strongest justification for locating thrifts within a managerial regime is our vital need for a well-functioning bank and thrift industry.

relationship between investment banking czar Michael Milken and his principal lawyer Arthur Liman, a partner in one of New York's most prestigious law firms, does not substantially resemble the relationship between most criminal defendants and their lawyers). Nonetheless, an OTS defendant is still placed in a relatively weak position when confronting the state.

347. See First Nat'l Bank v. Department of the Treasury, 911 F.2d 57, 64 (8th Cir. 1990) (referring to an Office of the Comptroller of the Currency civil penalty as a "penal sanction"); $c f$. United States v. Halper, 490 U.S. 435, 449-50 (1989) (extending double jeopardy protections to civil procecdings seeking very large penalties). Following Halper, commentators have called for other enhanced procedural protections in civil proceedings where the government seeks very large penalties. See, e.g., Cheh, supra note 245 , at 1384-89 (arguing that the privilege against self-incrimination should also extend to such proceedings).

348. 12 U.S.C. $\$ 1818(\mathrm{i})(2)(\mathrm{D})$ (Supp. IV 1992).

349. Cf. Baxter, supra note 41 , at $\$ 194$ (noting the "unduly punitive approach to banking supervision"). 
Depository institutions have always been among the most heavily regulated entities in the American economy. ${ }^{350}$ This extensive regulation reflects the American political system's long-standing and deeply rooted belief that depository institutions are "special"; their crucial roles as providers of credit to businesses and households and as custodians of funds deposited by the rest of the economy make them special. ${ }^{351}$ It has been argued that "[t]he continued economic growth of this country is clearly dependent upon the existence of financially sound and capably managed private lending institutions." ${ }^{352}$ The S\&L debacle of the 1980s evidences the disastrous consequences that can result when we fail to regulate such institutions efficiently. ${ }^{353}$

Along that same line, we may feel relatively comfortable with the OTS system because it implicates only a small, relatively discrete group of entities in our society. ${ }^{354}$ The people who are subject to OTS's managerial authority are generally well aware of that fact ${ }^{355}$ and have chosen to place themselves in that position. However, appeals to consent may be problematic where it is the government that is exercising managerial authority over citizens.

On the one hand, an organization's use of managerial authority over its members is generally considered appropriate because the members voluntarily joined the organization; that is, they consented to the organization's authority over them. ${ }^{356}$ One could argue analogously, then, that persons who choose to enter the highly regulated thrift industry consent to OTS's managerial control over them. Courts have reasoned along these lines in the Fourth Amendment context: certain administrative inspections in industries that are pervasively regulated or that have a long history of regulation are exempt from Fourth Amendnient protections on the ground that heavily regulated industries do not expect much privacy. ${ }^{357}$

On the other hand, the notion of consent may be troubling in the realm of governmental authority over citizens since consent implies free choice; if the government imposes managerial authority over too many aspects of life, then the "consent" will be rendered a fiction. Thus, it seems that we come back to the question of how limited the scope of the regulation is.

350. WhrTe, supra note 10 , at 25 ; LASH, supra note 14 , at vii.

351. WHITE, supra note 10 , at 25 .

352. S. Rep. No. 1482, 89th Cong., 2d Sess. (1966), reprinted in 1966 U.S.C.C.A.N. 3532, 3536.

353. The collapse of the savings and loan industry has been described as "the greatest regulatory fiasco in American history." ErcHLER, supra note 12, at vii. The cost to taxpayers has been estimated at upwards of \$1 trillion. Felsenfeld, supra note 12, at S29 \& n.144.

354. However, one might well argue about the scope of "institution-affiliated parties." See supra notes $49-52$ and accompanying text.

355. Concededly, Kaye Scholer seemed unaware that it was subject to OTS's managerial authority, but that is because it misinterpreted the role of its client in the regulatory system. Other law firms are not likely to make the same mistake in the OTS context or in a similar regulatory context.

356. Post, Between Governance, supra note 318, at 1785.

357. See supra notes $273-74$ and accompanying text. 
Although we may very well decide that managerial authority is appropriate and justified in the OTS context, we may still wish to be somewhat cautious about such authority due to the tendency of instrumental rationality to feed on itself and expand its power. ${ }^{358}$ One possible example of this expansion can be seen in the recent enhancements to the SEC's enforcement powers. FIRREA granted broad powers to OTS as a result of the calamitous S\&L scandal. Soon after, but with no similar provocation, Congress replicated virtually the same powers for the SEC despite the admonitions of commentators who counseled against enhancing the powers. ${ }^{359}$

This concern about the expansion of managerial authority points out the importance of simply recognizing when the government is establishing managerial structures of authority. In the Kaye Scholer case we found that discussing legal ethics rules in isolation did little to advance our understauding of what is more fundamentally at stake in the case. We must first be aware that we are being subject to managerial authority so that we can make informed, principled choices about whether the managerial structure is appropriate in the given domain, and more importantly, so that we can take steps to control the structures we have created instead of allowing them to control us.

358. As Professor Post compellingly described it,

[W] ought not to be quite so quick to embrace a world of "undeviating organization" (as members of the Frankfurt school would characterize it). The nightmare vision of Michel Foucault demonstrates clearly enough the true nature of such a world. Structures of control acquire their own life, turn, and bite the progressive hand that establishes them.

Post, supra note 212, at 677 (footnote omitted) (quoting THEODOR W. ADORNO \& MAX HORKHEIMER, Dialectic of EnLightenment 87 (John Cumming trans., 1972)).

359. See, e.g., Pitt \& Johnson, supra note 153, at 30 n.36 (" However familiar the FIRREA provisions are now to the members of Congress who struggled so in ensuring their adoption, they are not necessarily provisions that should be provided to the other agencies, such as the Securities and Exchange Commission.' ") (quoting Letter from ABA Section of Business Law to Donald W. Riegel, Jr., Chairman, Committee on Banking, Housing and Urban Affairs (May 18, 1990)). 